\title{
Experimental evidence of condensation-driven airflow
}

P. Bunyard ${ }^{1}$, M. Hodnett ${ }^{2, a}$, G. Poveda ${ }^{3}$, J. D. Burgos Salcedo ${ }^{4}$, and C. Peña ${ }^{5}$

${ }^{1}$ IDEASA, Universidad Sergio Arboleda, Bogotá, Colombia

${ }^{2}$ Centre for Ecology \& Hydrology, Wallingford, UK

${ }^{3}$ Department of Geosciences and Environment, Universidad Nacional de Colombia, Sede Medellín, Colombia

${ }^{4}$ Corporación para la Investigación y la Innovación - CIINAS, Bogotá, Colombia

${ }^{5}$ Facultad de Matemática, Universidad Sergio Arboleda, Bogotá, Colombia

${ }^{a}$ retired

Received: 20 August 2015 - Accepted: 5 October 2015 - Published: 27 October 2015

Correspondence to: P. Bunyard (pbecologist@gn.apc.org)

Published by Copernicus Publications on behalf of the European Geosciences Union.

\section{Experimental}

evidence of

condensation-driven

airflow

P. Bunyard et al.

Title Page

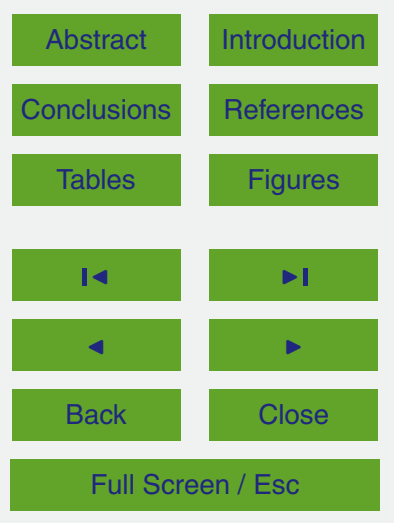

Printer-friendly Version

Interactive Discussion 


\section{Abstract}

The dominant "convection" model of atmospheric circulation is based on the premise that hot air expands and rises, to be replaced by colder air, thereby creating horizontal surface winds. A recent theory put forward by Makarieva and Gorshkov $(2007,2013)$ 5 maintains that the primary motive force of atmospheric circulation derives from the intense condensation and sharp pressure reduction that is associated with regions where a high rate of evapotranspiration from natural closed-canopy forests provides the "fuel" for cloud formation. The net result of the "biotic pump" theory is that moist air flows from ocean to land, drawn in by the pressure changes associated with a high rate of condensation.

To test the physics underpinning the biotic pump theory, namely that condensation of water vapour, at a sufficiently high rate, results in an uni-directional airflow, a $5 \mathrm{~m}$ tall experimental apparatus was designed and built, in which a $20 \mathrm{~m}^{3}$ body of atmospheric air is enclosed inside an annular $14 \mathrm{~m}$ long space (a "square donut") around which it can circulate freely, allowing for rotary air flows. One vertical side of the apparatus contains some $17 \mathrm{~m}$ of copper refrigeration coils, which cause condensation. The apparatus contains a series of sensors measuring temperature, humidity and barometric pressure every five seconds, and air flow every second.

The laws of Newtonian physics are used in calculating the rate of condensation inside the apparatus. The results of more than one hundred experiments show a highly significant correlation, with $r^{2}>0.9$, of airflow and the rate of condensation. The rotary air flows created appear to be consistent both in direction and velocity with the biotic pump hypothesis, the critical factor being the rate change in the partial pressure of water vapour in the enclosed body of atmospheric air. Air density changes, in terms of kinetic energy, are found to be orders of magnitude smaller than the kinetic energy of partial pressure change.

The consistency of the laboratory experiments, in confirming the physics of the biotic pump, has profound implications for current mathematical climate models, not just in

Experimental

evidence of

condensation-driven airflow

P. Bunyard et al.

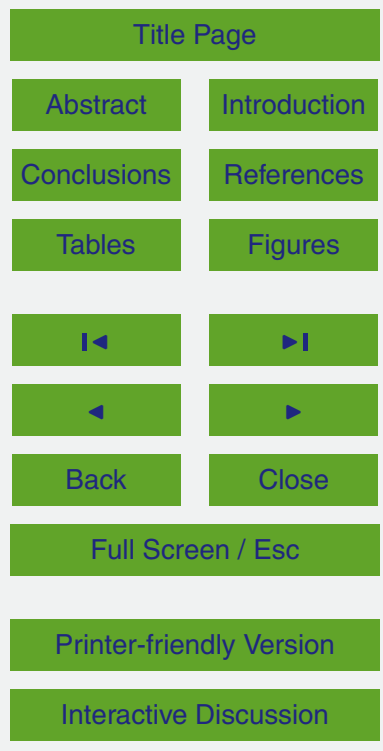


terms of predicting the consequences of widespread deforestation, but also for better understanding the atmospheric processes which lead to air mass convection.

\section{Introduction}

Atmospheric convection, which leads to air mass circulation, is generally considered to 5 result from the lower atmosphere acting as a heat engine, with the kinetic energy for convection deriving from differences in temperature, according to the general principle that hot air rises and cold air sinks. However, as Makarieva et al. (2013) point out, when hot air rises in the lower atmosphere it cools because of expansion and when the same, but now cooler, air sinks it heats up, such that the overall gain or loss in kinetic 10 energy is zero. The same cooling and heating happens when air expands and forces air elsewhere to compress; there is no net energy gain to do work. In other words, a strict application of the first law of thermodynamics to the atmosphere would yield a rate of kinetic energy generation equal to zero.

Instead, the same authors (2013) present the notion that the potential energy, 15 derived from an outside source (the Sun), is stored in the evapotranspiration of water which, on condensing, converts into kinetic energy, and so drives the process of air mass convection. During daylight hours closed-canopy forests pump more than double the quantity of water vapour per square metre of surface compared to the ocean in the same latitude, the net result being that condensation in cloud-forming over the forest causes surface air to flow upwards, thereby generating low pressure at the surface which, in turn, establishes an ocean-to-land pressure gradient (Makarieva et al., 2013, 2014).

By means of evapotranspiration, rainforests, whether in the equatorial tropics or in boreal regions during summer months, feed the lower atmosphere with water vapour, 10923 
point of view, it is the hydrological cycle, including water evaporation and condensation, which drives convection and therefore the circulation of the air masses. That is in sharp contrast to the orthodox view of convection and air mass circulation, which explains the movement of the air mass through latitudinal differences, helped on by the release of latent heat.

The proposition that a high rate of evapotranspiration from forested regions is a prime mover of major air mass convection has remained contentious. Meesters et al. (2009) rejected the BPT on the grounds that the ascending air motions induced by the evaporative/condensation force would rapidly restore hydrostatic equilibrium 10 and thereby become extinguished. In reply Makarieva et al. (2009) pointed out that condensation removed water vapour molecules from the gas phase and reduced the weight of the air column. That removal must disturb hydrostatic equilibrium and make air circulate under the action of the evaporation/condensation force (Makarieva, 2009).

The mass of an air column is equal to the number of air molecules in the column 15 multiplied by their molecular masses. When the number of air molecules in the column is preserved, its weight remains unchanged and independent of density. Hence, heating of the air column does not change its weight. In contrast, condensation changes the number of gas molecules in the air column and instantaneously reduces the weight of the air column irrespective of the effects it might have on air density (Makarieva, 2009). In effect, the BPT states that the major physical cause of moisture fluxes is not the non-uniformity of atmospheric and surface heating, but that water vapour is invariably upward-directed as a result of the rarefaction of air from condensation (Makarieva, 2013).

The BPT, therefore, maintains that the air pressure sustains its disequilibrium 25 because of the reduction in total weight of the air column as condensation occurs, that being a continuous process as the ascending moist air cools. In fact, when the initial bulk air pressure in the lower atmospheric levels no longer equals the bulk weight of the air column, the initial hydrostatic equilibrium of air as a whole is disturbed and an accelerating upward motion is initiated in the air column. This upward motion of
HESSD

12, 10921-10974, 2015

Experimental

evidence of

condensation-driven airflow

P. Bunyard et al.

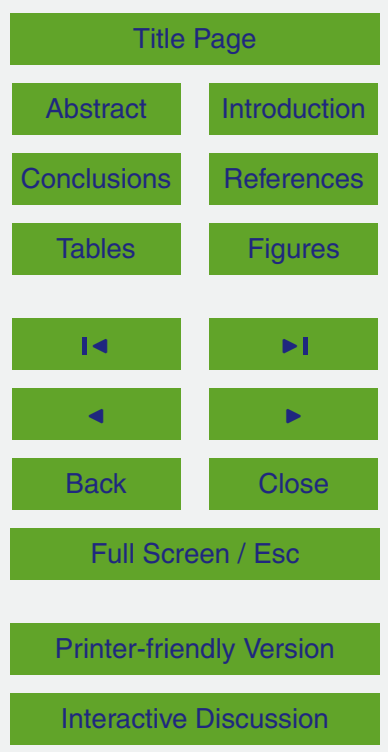


expanding and cooling moist air sustains the continuous process of condensation and does not allow the hydrostatic equilibrium of air as a whole to set in. The motion continues as long as there is water vapour in the rising air to sustain condensation (Makarieva, 2009). Within the concept of the biotic pump it is the physical mechanism 5 of condensation which drives the upward airflow in the lower atmosphere by removing molecules from the air column, and thus generates the surface horizontal winds, such as the Trade Winds.

Evidence in favour of the BPT has come from a number of different sources. Makarieva et al. $(2007,2013)$ refer to data showing that precipitation over river basins 10 which are covered in forest remains as high in the deep interior of the continent as at the coast, whereas river basins without forest show an exponential decline in rainfall as one passes from the coast inland. Spracklen et al. (2012) have shown from their recent pan-tropical study of rainfall and land-cover, as indicated by the leaf area index (LAI), that satellite-derived rainfall measurements are positively correlated with the degree to 15 which model-derived air trajectories have been exposed to forest cover. Even though Makarieva and colleagues (2014) have some essential criticisms of the methodology used by Spracklen, they conclude that the Spracklen results confirm the influence of forest on regional rainfall patterns.

In a recent study, Poveda et al. (2014) provide evidence that when the low level 20

jet streams pass over forested regions, precipitation levels stay high and constant, whereas over regions which lack forest, precipitation levels decline exponentially, just as the BPT suggests should happen. Poveda and his colleagues look the low level Chocó jet and comment that the change in direction of the Pacific Austral Trade Winds from Easterlies to Westerlies just over the Equator at $4^{\circ} \mathrm{N}$, may owe their abrupt switch in great part to the unsurpassed degree of evapotranspiration and subsequent condensation over the Chocó rainforest in Colombia.

With more than $380000 \mathrm{~m}^{3}$ per second of water vapour being brought in from the Tropical Atlantic Ocean, (Salati, 1987) the Amazon Basin functions on a far grander scale than the Chocó. It would appear that evapotranspiration rates are sufficiently

HESSD

12, 10921-10974, 2015

\section{Experimental}

evidence of

condensation-driven airflow

P. Bunyard et al.

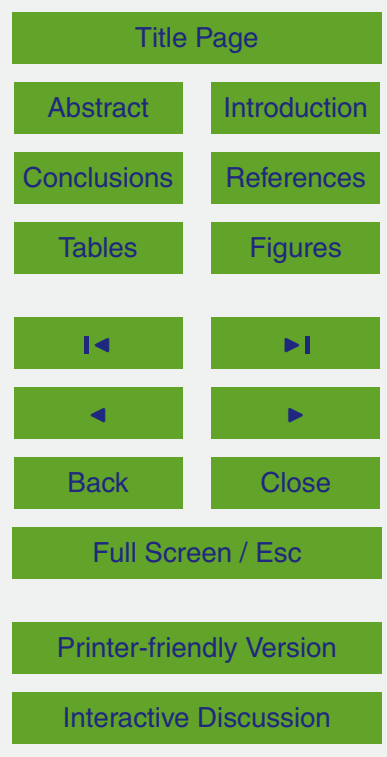


high over the rainforest to increase the volume of the Amazonian atmospheric river in the form of the South American Low Level Jet Stream as it approaches the western reaches of the Amazon Basin and is then deflected both upwards and southwards on encountering the Andes (Marengo, 2006; Poveda, 2014).

5 Builes-Jaramillo and Poveda (2015) have now extended their research to look at possible correlations between the flow of the Northwest Trade winds and the different seasons encountered over the Amazon Basin. They have found an inverse correlation between sea surface temperatures (SSTs) in the North Tropical Atlantic and an increase in the seasonal index of precipitation minus evapotranspiration ( $P$ $10 \mathrm{E})$. Whereas the SST has a minimum in February, the P-E for the Amazon shows a maximum in March. Vice versa the P-E has a minimum in August followed by an SST maximum in September. Sea surface temperatures are influenced by the velocity of the surface winds, the Northwest Trade Winds, and the evaporation of water. The rainy season over the rainforest in March is associated with dense clouds and condensation. On the basis of the BPT, intense condensation will lead to stronger surface winds over the North Tropical Atlantic; hence their lower temperatures. The corollary is that reduced cloud formation over Amazonia will lead to reduced surface flow of the Trade Winds; hence higher SSTs. These findings have considerable implications for global climate, indicating that widespread deforestation could lead to warmer SSTs and therefore presumably to more extreme climatic events, including hurricanes, over the tropical North Atlantic.

Overall, the evidence for the BPT is accumulating, but contention will remain until the physics underlying the convection model and the BPT can be clearly defined and distinguished. For that reason, this paper describes an attempt to study the physics in
HESSD

12, 10921-10974, 2015

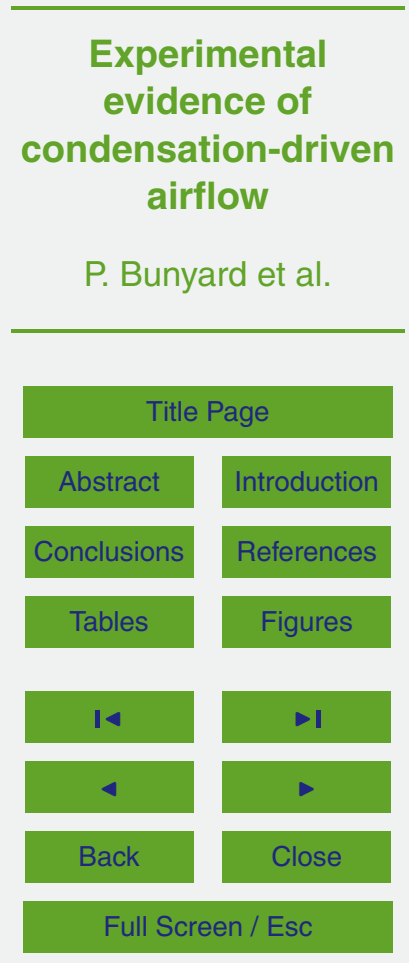

Printer-friendly Version

Interactive Discussion 


\section{Methodology}

To test the underlying physics of the impact of condensation upon airflow, the idea was conceived of an enclosed structure which would allow a measurable air circulation to take place under conditions of controlled condensation. The structure (Fig. 1) consists 5 of two columns, made of insulated PVC, $4.8 \mathrm{~m}$ high, with a cross-sectional area of $1.44 \mathrm{~m}^{2}$, connected at the top and bottom by "tunnels" $2.4 \mathrm{~m}$ long with the same crosssectional area of $1.44 \mathrm{~m}^{2}$. On account of small leaks some mixing of the enclosed air with the external air may take place, but the dynamics of each experiment swamp the impact of any such exchanges, and to all intents and purposes the structure is leakproof. However, despite the insulation, the structure is affected by external temperature and by differential insolation. The effect of external insolation is measurable by means of directional airflow and is accounted for in determining the relationship between the rate of condensation and consequent airflow.

Access to each column is by means of an insulated PVC door, with double glazing 15 to allow a view inside. A double-layer of copper refrigeration coils, $17 \mathrm{~m}$ in length and $12 \mathrm{~mm}$ in external diameter, are located $3.4 \mathrm{~m}$ up the right-hand column, approximately $20 \mathrm{~cm}$ down from the junction between the column and the upper tunnel. The total surface area of the coils, taking a $3.0 \mathrm{~mm}$ coating of ice into account, is $0.96 \mathrm{~m}^{2}$; they are connected to an industrial compressor located some $3 \mathrm{~m}$ away on the floor of the laboratory. The laboratory is contained within a lean-to. The right-hand column, as viewed from within the laboratory, and as shown in Fig. 1, is likely to get more insolation, because of its easterly orientation, than the left-hand column which is shaded from the southerly sun by beech trees. That difference in orientation results in the "default" air movement being counter-clockwise, with air rising in the "right" column and sinking in the "left".

Sensors, including thermocouples $(\mathrm{T})$, hygrometers $(\mathrm{RH})$ and barometric pressure gauges, (BAR) have been judiciously placed, in locations 1, 2 and 3 in Fig. 1, so as to obtain measurements of changing conditions every five seconds within the columns

HESSD

12, 10921-10974, 2015

Experimental

evidence of

condensation-driven

airflow

P. Bunyard et al.

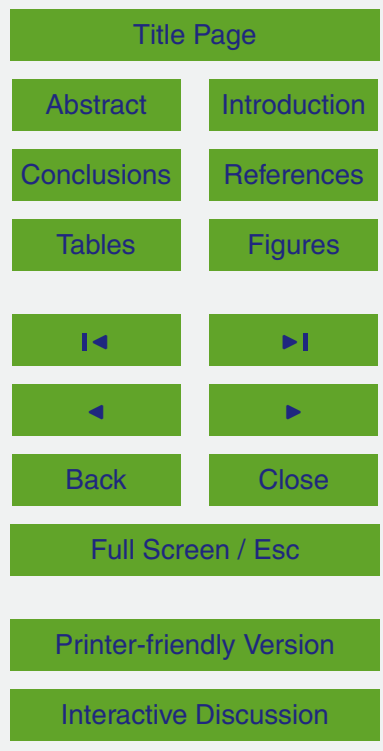

Interactive Discussion 
and tunnels. The Gill 2-D ultrasonic anemometer (UA), measuring every second, is located $15 \mathrm{~cm}$ up from the floor of the upper tunnel and some $5 \mathrm{~cm}$ from the junction between the tunnel and the right-hand column. When the airflow in the upper tunnel is direct from the left-hand column to the right-hand column the directionality is given as $5180^{\circ}$ and is close to either 360 or $0^{\circ}$ when the flow is reversed. (See Fig. 1).

Prior to the initiation of an experiment, the entrapped air, having been in contact with the external environment, displays similar characteristics as the air outside in terms of temperature, pressure and humidity. However, once the doors, located at the bottom of each column, are closed the structure remains sufficiently airtight to permit the changes 10 to temperature, to humidity and to local pressure brought about during the course of an experiment to be observed and recorded. The relative humidity can be reduced to $30 \%$ in the enclosed air through the use of an industrial dehumidifier. The dehumidifier is always switched off and any collected water taken away before an experiment is begun.

15 Standard physics is applied to the results (Mcllveen, 2010), with separate calculations for the top tunnel (1), the parcel of air affected per second at the cooling coils (2), and the lower section of the right hand column (3). To determine the partial pressure of water vapour at $5 \mathrm{~s}$ intervals, the standard Clausius-Clapeyron equation is used. Since at an atmospheric pressure of $1013.25 \mathrm{hPa}, p_{2}$, water boils at $373 \mathrm{~K}$, represented as $T_{2}$ it is possible to substitute for $p_{2}$ and $T_{2}$, and at each temperature, $T_{1}$, to determine the saturated partial pressure of water, $p_{1}$, for the three locations $(1,2$ and 3). (See Fig. 1, Eqs. 1 and 2).

$\ln \frac{p_{2}}{p_{1}}=\frac{Q\left(T_{2}-T_{1}\right)}{R T_{2} T_{1}}$

Or

${ }_{25} \log p_{2}-\frac{Q\left(T_{2}-T_{1}\right)}{R T_{2} T_{1} \cdot 2.303}=\log p_{1}$
HESSD

12, 10921-10974, 2015
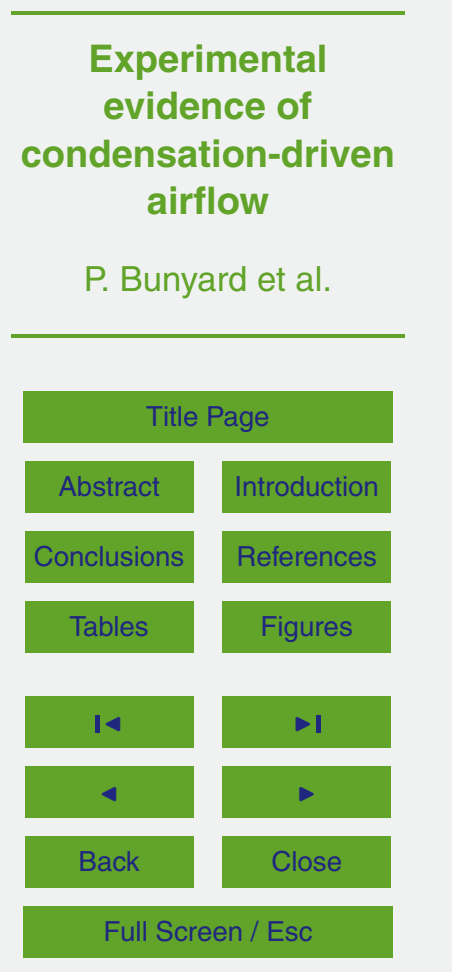

Printer-friendly Version

Interactive Discussion 
Where $Q$, Latent heat of Evaporation, $=40.65 \mathrm{~kJ} \mathrm{~mol}^{-1}$ and $R$, the ideal gas constant, is $8.3 \mathrm{JK}^{-1} \mathrm{~mol}^{-1}$. The actual partial pressure of water vapour, $p_{1}$ in the three locations, is given by multiplying the result by the relative humidity, $\mathrm{RH}$, as measured by the hygrometers, placed in all three locations (Fig. 1).

The air density, at that moment in time, is obtained through the use of the equation of state for ideal gases, namely,

$p=\rho R T$,

where $p$ is the barometric pressure (hPa), $\rho$ is the air density in $\mathrm{kg} \mathrm{m}^{-3}, R$ is the ideal gas constant, $\mathrm{JK}^{-1} \mathrm{~mol}^{-1}$ and $T$ is the temperature in Kelvin. Since $R$ varies with the degree of humidity in the air, the equation as below is applied, using the values $287 \mathrm{~J} \mathrm{~K}^{-1} \mathrm{~kg}^{-1}$ for dry air and $461 \mathrm{~J} \mathrm{~K}^{-1} \mathrm{~kg}^{-1}$ for water vapour:

$R=(461 \cdot r)+(1-r) \cdot 287$

$r$ is the absolute humidity of water vapour in dry air, hence $\mathrm{kg}$ of water vapour per $\mathrm{kg}$ of dry air. The value of $R$, the ideal gas constant for moist air, as water vapour is added or 15 removed, is shown to vary by as much as 1.5 , for example, from 288.9 to 287.5 during the course of an experiment.

To obtain $r$ we need first to obtain $q$, the absolute humidity of water vapour $\mathrm{kg}$ per $\mathrm{kg}$ of moist air using (Mcllveen, 2010):

$q=\frac{\left(0.622 \cdot p_{\mathrm{wv}}\right)}{p_{\mathrm{atmos}}-p_{\mathrm{wv}}}$

where 0.622 is the ratio of the effective molecular weights of water vapour and dry air, hence 18/29; $p_{\text {atmos }}$ is the barometric reading at that moment in time for the three locations and $p_{\mathrm{wv}}$ is the partial pressure of water vapour, as calculated at the same time of reading. Then, to convert $q$, the absolute humidity for moist air, to the absolute humidity for dry air, $r$, the following formula is used:

${ }_{25} r=\frac{q}{1-q}$.
HESSD

12, 10921-10974, 2015

\section{Experimental \\ evidence of \\ condensation-driven \\ airflow \\ P. Bunyard et al.}

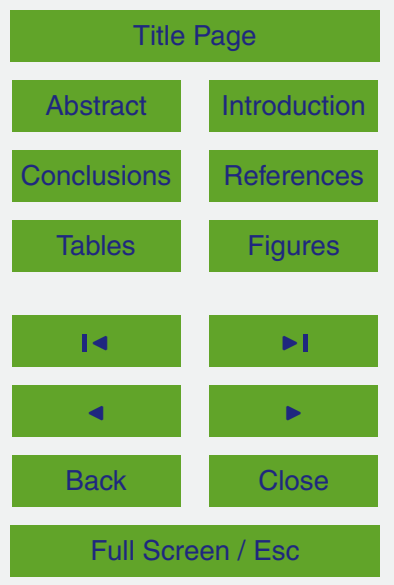

Printer-friendly Version

Interactive Discussion 
To calculate the absolute humidity, $h$ (water vapour in grams per cubic metre of moist air), the values of $q$ and $\rho$, (the air density in $\mathrm{kg} \mathrm{m}^{-3}$ ) are required, as are the values for $R$ and $T$.

The air density, $\rho$, in $\mathrm{kg} \mathrm{m}^{-3}$, is obtained using the ideal gas equation, where the 5 barometric pressure is given in Pascals:

$$
\frac{p}{R T}=\rho
$$

Therefore the humidity in grams per cubic metre of moist air will be obtained from:

$$
h=q \rho 1000
$$

In order to obtain the kinetic energy values changes in the partial pressure of water

$\mathrm{J}=\mathrm{kg} \cdot \frac{\mathrm{m}^{2}}{\mathrm{~s}^{2}}=\mathrm{Nm}=\mathrm{Pa} \cdot \mathrm{m}^{3}=\mathrm{Ws}$

Whereby $\mathrm{J}$ is joules, $\mathrm{N}$ is Newtons, $\mathrm{Pa}$ is Pascals and $\mathrm{W}$ is Watts. Thereby, the Ws for both the partial pressure change in the condensing parcel of air and the change in air density can be calculated. The resulting quantity can then be converted into the velocity of the airflow (Boyle, 1998):

$\mathrm{Ws}=0.5 \cdot \rho \cdot A \cdot v^{3}$,

where $\mathrm{W}$ is Ws, $\rho$ is the air density in $\mathrm{kg} \mathrm{m}^{-3}$ and $v^{3}$ is the cube of the velocity $\left(\mathrm{ms}^{-1}\right)$. The area, $A$, is taken as the surface area of the condensing coils, $0.963 \mathrm{~m}^{2}$. Good correspondence is obtained graphically when the calculated airflow is compared with the actual measured airflow (see Fig. 26). Equation (10) gives the ideal relationship between kinetic energy and airflow, as used in explaining the energy derived from wind turbines (Boyle, 1998). The velocity to the cube is because the length of traverse of 10930
HESSD

12, 10921-10974, 2015

\section{Experimental \\ evidence of \\ condensation-driven \\ airflow \\ P. Bunyard et al.}

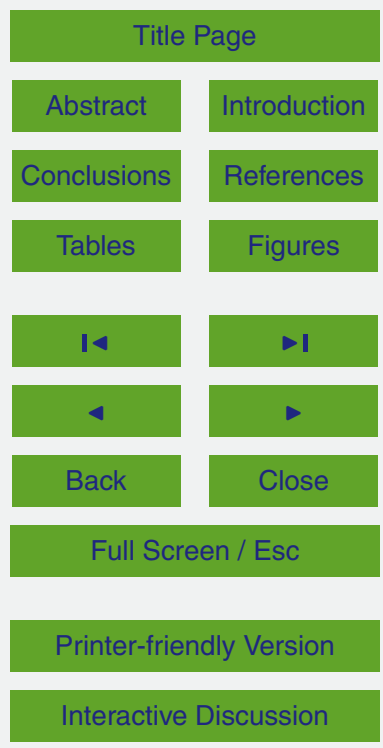

Interactive Discussion 
the air depends precisely on the velocity and therefore adds length to the surface area when calculating the volume.

The three variables of temperature, barometric pressure and relative humidity are all that is required to calculate the partial pressure of water vapour, using the exponential 5 equation of Clausius-Clapeyron, (Eqs. 1 and 2) and from that the absolute humidity and air density, (Eqs. 7 and 8) at any moment in time. It is then a simple task to convert the change in partial pressure at various points in the structure to kinetic energy in terms of Watt-seconds (Eqs. 7 and 8). Equally, the changing air densities of the same parcels of air can be converted to kinetic energy, making direct comparisons possible between the potential forces (Eq. 9).

The physics used in the calculations presented here are encapsulated in the following flow chart, which serves the experimental data as well as the data from radiosoundings and surface meteorological stations (Bunyard, 2014; Bunyard et al., 2012).

\section{Results}

15 More than 100 experiments, each lasting approximately $50 \mathrm{~min}$, demonstrate that sudden changes in the partial pressure of water vapour at the point of cooling lead to a measurable, clockwise circulation of air, which increases and decreases according to the rate of change of the partial pressure. The relationship follows a power law between the rate of change in the partial pressure of water vapour $\left(\mathrm{hPas}^{-1}\right)$ and the airflow $\left(\mathrm{m} \mathrm{s}^{-1}\right)$. It results in a circulation throughout the $14 \mathrm{~m}$ length of the experimental structure as air is drawn from the top tunnel into the area of condensation and then downwards, passing in a clockwise direction from the right-hand column to the left column and upwards into the upper connecting tunnel (Fig. 1). In terms of power delivered (kinetic energy as Ws) the condensation of water vapour, in a chilled parcel of air with a volume some 430 times smaller than that of the total volume of enclosed air, is between two and four orders of magnitude greater than that of the air density change

\section{HESSD}

12, 10921-10974, 2015
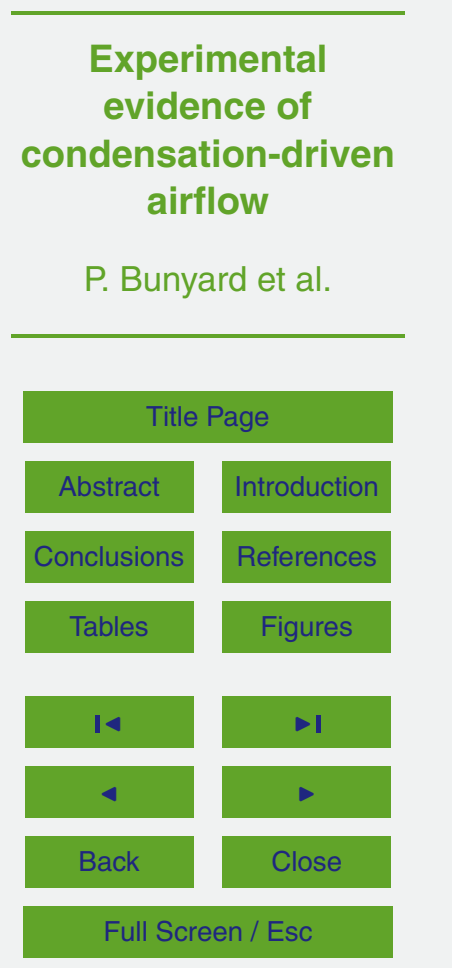

Printer-friendly Version

Interactive Discussion 
measured for the same parcel of air, the difference in magnitude corresponding to the relative "dryness" of the air (see Fig. 3 and Eq. 9).

Through taking account of changes in temperature, relative humidity and barometric pressure from the strategically-placed sensors (Fig. 1, Eq. 2 to 9), the different forces 5 which come into play can be distinguished, namely:

1. Changes in the partial pressure of water vapour through condensation, melting and re-evaporation (Experiments 1 to 4, Figs. 4, 6, 8, 10, and 25) and their correspondence to airflow;

2. Changes in the air density of the chilled parcel air, measured in Watts as it passes over the cooling coils with comparisons to the kinetic energy of partial pressure change from condensation (Experiments 1 to 4, Figs. 15, 16, 17, and 18);

3. The ideal airflow (Eqs. 9 and 10, Figs. 26 and 27) and how the airflow caused by condensation overcomes the airflow in the counter direction caused by external differential heating of the two columns (Figs. 4, 5, and 25).

The airflow and condensation profiles for the four experiments shown result from different internal conditions, including temperature, relative humidity and differential heating, with the proviso that those internal conditions are affected over time by external conditions. In particular, small air exchanges between the external and internal environment take place over the course of time between experiments, but without impacting an experiment in course. The internal temperature is measurably affected by the external temperature and will register differential heating if the sun happens to be shining on one side of the structure, while the other remains in shade.

In all experiments, without exception, once the compressor is on and refrigeration takes place the directionality is close to $180^{\circ}$ and therefore the airflow is clockwise two factors: (a) the directionality of the airflow prior to switching on the compressor (Experiment 1, Figs. 4 and 5), (b) the rate of condensation as determined by the

\section{HESSD}

12, 10921-10974, 2015

Experimental

evidence of

condensation-driven

airflow

P. Bunyard et al.

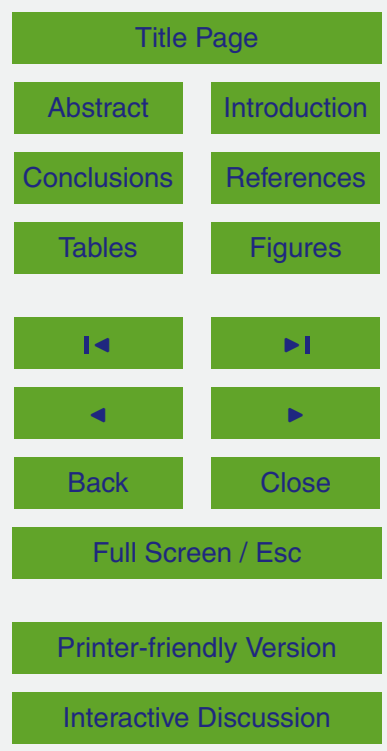

Interactive Discussion 
rate of change in the absolute (specific) humidity $r$ (Eq. 5 to 8, Figs. 11, 12, 13, and 14). When the initial airflow is counter-clockwise (Fig. 4 and 5), the airflow resulting from condensation takes over, and just as a cyclist battles against a headwind, so the condensation airflow is reduced from what it would be were there no "headwind". 5 Hence, accounting for headwind, the airspeed in experiment 1 would be $>0.2 \mathrm{~ms}^{-1}$.

The rate of change in specific humidity for the four experiments is seen in the following graphs (Figs. 11, 12, 13, and 14).

By means of applying the equations of state for water vapour and specifically Eq. (9), the kinetic energies of the rate of change in the partial pressure of water vapour from 10 condensation and of the air density in the same parcel of cooled air can be calculated. The resulting curves are shown in Figs. 15, 16, 17, and 18, and in each instance, at a particular moment in time, the ratio of air density change to that of partial pressure change can be determined.

With airflows of $0.15 \mathrm{~ms}^{-1}$, each parcel of air will take some $0.33 \mathrm{~s}$ to traverse the $150.05 \mathrm{~m}$ distance from the top to the bottom of the coils. Empirical evidence of the proper application of physical laws for ideal gases (Clausius-Clapeyron) is apparent through comparing the weight of condensed water obtained from the capture of precipitated water, with that obtained from theoretical considerations of the change in partial pressure of water vapour and hence in absolute humidity. The "rain" is gathered by means of a sloping-plane, hard plastic sheet, with a gutter at its lowest end. Any drops which fail to run into the gutter are mopped up with absorbent cloths and weighed.

By measuring (at location 2 in Fig. 1) the changes in humidity $h$ per second taking place in the parcels of air passing through the condenser, a profile of the changing water vapour content of the air is obtained (Eq. 8). The experiment of 8 February 2015, when the initial temperature was $-1.32^{\circ} \mathrm{C}$ and the barometric pressure $1038.85 \mathrm{hPa}$, gave a total condensation of $4.45 \mathrm{~g}$ which agreed with the quantity that precipitated. For the experiment of 27 July 2015, the accumulated condensate at 3000 s measured $50 \mathrm{~g}$ and the amount gathered was $51 \mathrm{~g}$.

HESSD

12, 10921-10974, 2015

\section{Experimental}

evidence of

condensation-driven airflow

P. Bunyard et al.

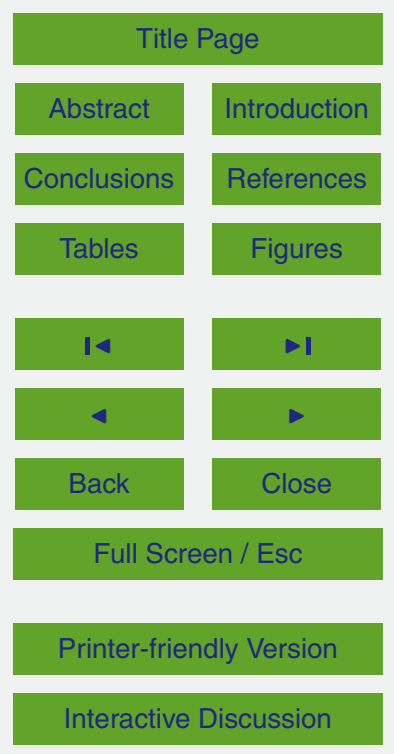


In general, the compressor for the cooling coils is switched off $15 \mathrm{~min}$ before the end of the experiment at $50 \mathrm{~min}$. That period allows the temperature to increase throughout the structure, and in particular in the section with the coolant coils, such that the ice melts and the liquid water falls as rain (sometimes as hail) onto the collecting sheet 5 which lies under the coils at the base of the right-hand column. Calculations of the expected fallout of rain accord closely to that collected (Figs. 19, 20, and 21).

When the initial relative humidity is low, i.e. less than $40 \%$, the ice-condensate on the coils is found to ablate directly into water vapour and hence cannot be collected. Calculations of the expected fallout of rain from an experiment take account of the 10 increase in absolute and relative humidity resulting from any such ablation. For instance, for Experiment 4, when the initial relative humidity had been reduced to $31 \%$, the quantity of rain collected at the conclusion of the experiment at 50 min amounted to 2 grams and the calculation of the expected fallout from changes in the humidity of the enclosed air in the experimental structure was 1.2 grams (Fig. 21).

15 When the final relative humidity in the experimental structure is above $60 \%$ then ablation appears to be minimal and the ice on the coils falls as rain as seen in Figs. 19 and 20.

The experimental results make it clear that the key to airflow resides in the rate of partial pressure change. The latent heat release, of the same kinetic energy as that negative pressure change, by warming the air and making it less dense, tends to generate a counter flow to that from water vapour condensation. Taking gravitational considerations into account the air moves downwards to the cooling coils rather than upwards, thus generating a clockwise circulation.

Each experiment, under different initial conditions and, during the course of the experiment generating its own particular conditions, follows the same pattern in terms of the partial pressure change from condensation and re-evaporation having a direct impact on the airflow as measured with the 2-D ultrasonic Gill anemometer. In Experiment 1 and 4, the reduction in pressure, during the time when the compressor is switched on and refrigeration is occurring, is indicated by the sensor in location 2 ,

\section{HESSD}

12, 10921-10974, 2015

\section{Experimental}

evidence of

condensation-driven airflow

P. Bunyard et al.

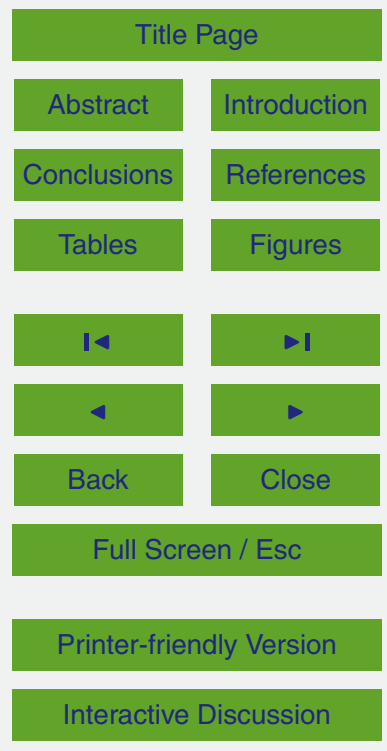


just beside the cooling coils (Fig. 1). That fall in pressure should be contrasted with the barometric readings from above the coils, in the upper tunnel at site No. 1 (Fig. 1). The fall in pressure at location 2, while the compressor is running, can be interpreted as signalling the proximate reduction in pressure as condensation occurs. The increase 5 in barometric pressure above the condensation coils in location 1, Fig. 1, could be registering the increase in air density from a simultaneous drop in temperature and in absolute humidity (Figs. 22 and 23).

If all the kinetic energy release from condensation and the reduction in partial pressure of water vapour were focussed into a single uni-directional flow, then the ideal 10 flow would be given by Eq. (10), the straight line being determined by taking the log of both axes (Fig. 24).

On account of the implosive pressure change as a result of condensation, the kinetic energy release will be from all angles. Nevertheless, flow tendencies will result because of other factors, such as gravity or, in the case of the atmosphere at large, the effect of the upper jet streams on the columns of air below. As a result, the ideal flow will not be encountered in the experiment, nor indeed in the atmosphere at large. In the experiments, the actual uni-directional flow from condensation is found to approximate one-fifth of the ideal flow. (Figs. 25 and 26). In all experiments, despite the different initial conditions and the timing and duration of the period of refrigeration, the close vapour is to be seen, as shown in Figs. 4, 6, 8, 10, and 25.

From the data, the kinetic energy in Watt-seconds can be calculated: (1) derived from the partial pressure change in water vapour, (2) from the air density rate change at the point of cooling, (3) the latent heat release (Fig. 27). The results are uniform and unequivocal in that the kinetic energy release from the imploding parcel of air, subjected to refrigeration, at an approximate rate of $0.33 \mathrm{~s}$ per parcel of volume $0.048 \mathrm{~m}^{3}$, when the unidirectional clockwise velocity of air is $0.15 \mathrm{~m} \mathrm{~s}^{-1}$, is sufficient to account for the airflow. The kinetic energy release from the change in air density in the same parcel of air is between two and four orders of magnitude less than the partial pressure change

\section{HESSD}

12, 10921-10974, 2015
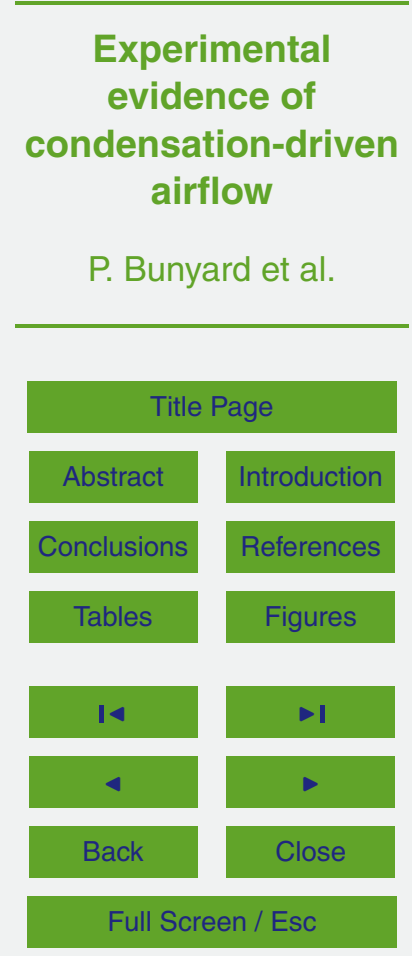

Printer-friendly Version

Interactive Discussion 
over the same time period, the difference depending on the relative humidity at the start of each experiment (Figs. 3, 15, 16, 17, and 18).

The correspondence between the airflow $\left(\mathrm{ms}^{-1}\right)$ and the partial pressure change $(\mathrm{hPa})$ becomes clear from more than one hundred experiments when analysed against 5 the rate of change per second of the specific (absolute) humidity. The relationship between the partial pressure change in water vapour and the change in specific humidity follows a straight line through the origin with an $r^{2}$ of 0.9956 ; the relationship of the airflow to the change in specific humidity follows a power law curve with an $r^{2}$ of 0.964 (Fig. 28).

10 Meanwhile the relationship between the airflow and the change in partial pressure of water vapour follows a power law, as expected, with an $r^{2}$ of 0.9761 . The ideal curve of the airflow from the kinetic energy of the partial pressure change closely follows the trajectory of the measured airflow (Fig. 29).

The chilled parcel of air not only has a kinetic energy equivalent to three orders of 15 magnitude less than that of the change in the partial pressure of water vapour but the correlation with the airflow is substantially weaker than is seen with either the change in absolute humidity or the partial pressure change (Fig. 30).

Finally, significant correlations are encountered when the changing rate of partial pressure as a result of condensation is matched against airflow, as seen in Figs. 31 and 32 for two different experiments.

Table 1 displays data derived from the right-hand column of Experiments 1 to 4 .

\section{Discussion}

The highly significant difference in the kinetic energy value of the observed partial pressure change compared to that of the observed air density change in the same cooled parcel of air suggests that the notion of the fundamental importance of water vapour condensation in driving mass air convection is correct (Table 1). Latent heat release on condensation dissipates rapidly in the surrounding medium, providing

Experimental

evidence of

condensation-driven airflow

P. Bunyard et al.

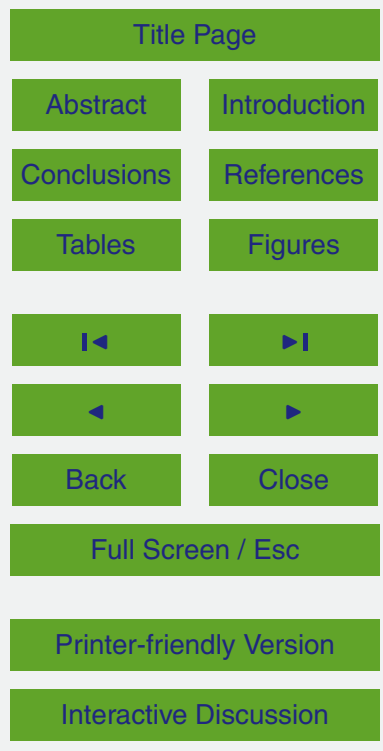


thermal radiation, and is ultimately lost to the environment. The latent heat release from condensation in terms of kinetic energy is equal to kinetic energy calculated for the partial pressure change resulting from the same condensation (Fig. 27). That confirms the physical relationship between partial pressure change and the energy involved in 5 the phase transformation from vapour to liquid and ice, the latter being measurable after it melts and falls, either as rain or hail. Even though the latent heat is dissipated to the surrounding air, thus offsetting the cooling from the refrigeration coils, and in principle tending to cause the air to rise rather than sink, in a counter-clockwise motion, the circulation still flows in a clockwise direction.

10 Given the ratio between the air density change and partial pressure change in the same parcel of air, we conclude that the force majeure in causing the circulation is the partial pressure change. Meanwhile, the clockwise directionality in the experimental structure is the result of the relative mass difference between the volume of air above the cooling coils compared to that below; hence more than three times of air mass below compared to above. Given the experimental set-up, the net result of the difference in air mass above and below the cooling coils is that the drawing in of air as the partial pressure reduces will more easily be from above rather than below. Once the circulation is set in motion it is maintained preferentially by the flow of air from above which in its turn undergoes cooling and condensation. In general, at an airflow averaging $0.15 \mathrm{~m} \mathrm{~s}^{-1}$, three parcels of air of volume $0.048 \mathrm{~m}^{3}$ should pass over the coils per second. The cooler air below the coils will increase the likelihood of the flow during condensation being in the clockwise direction, although as pointed out, the energies involved are negligible compared to the energies liberated when water vapour condenses.

During some experiments, especially when the summer sun was differentially heating the structure, counter-clockwise flow was observed; presumably caused by air density changes, with hot air rising and cooler air sinking (Figs. 4 and 5). Since each column contains more than 200 times the volume of air compared to the parcel of air passing over the condensing coils, the kinetic energy contained in the warmer air is therefore

\section{HESSD}

12, 10921-10974, 2015

\section{Experimental}

evidence of

condensation-driven airflow

P. Bunyard et al.

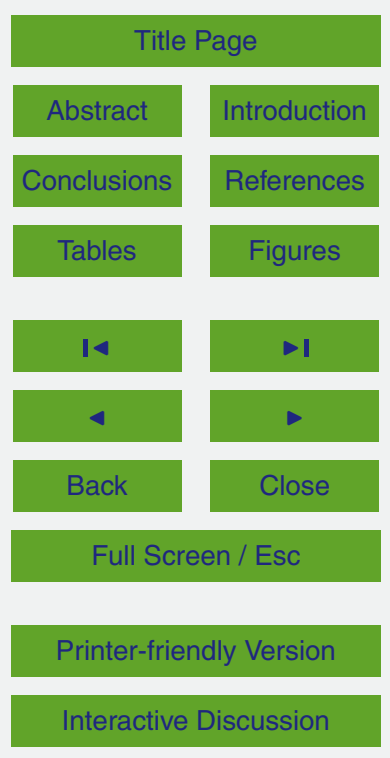


sufficient to drive the airflow. That airflow, nonetheless, is generally weaker by one half or more than that obtained when cooling the coil-associated parcel of air, even though in volume it is 430 times smaller. That finding confirms that air density changes are considerably weaker in their impact on airflow than that of partial pressure change 5 brought about through condensation.

Makarieva (2007) argues that the high rate of condensation over the tropical rainforest, fed by evapotranspiration, will lead to surface airflow as a result of the pressure change (1200-fold reduction in volume of each gram molecule of water vapour condensed). If so, then the experimental findings, described in the previous section, and all based on the fundamental physics of ideal gases, can be extrapolated to the wider arena of the earth's atmosphere inasmuch as the same physics should prevail during cloud formation and dissipation.

The energies in evapotranspiration from the rainforest and natural ecosystems are enormous when totalled for the entire 6 million $\mathrm{km}^{2}$ of the Amazon Basin, being 15 equivalent in brute energetic terms to 15 atomic bombs every second, (each 15 kT of TNT) (Salati, 1987). Equally, the conventional reason for the reduction in the environmental lapse rate (ELR) from 9.8 to $5^{\circ} \mathrm{C}$ or less per kilometre altitude when the air is humid refers to the release of latent heat on condensation, which warms the surrounding air. That is certainly true, but based on the biotic pump principle, could it be that the rate of cooling reduces per altitude because warm surface air is sucked upwards at a rate faster than were it to be dry air which consequently does not undergo condensation? That being the case, the high rate of condensation over the rainforest will increase horizontal flow and, as a result, the transportation of more water vapour from the tropical Atlantic Ocean. The experimental results provide a clue as to the

\section{HESSD}

12, 10921-10974, 2015

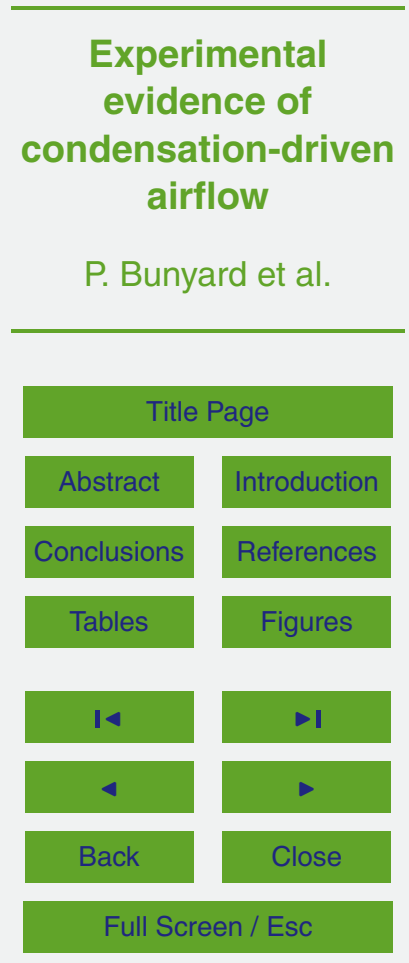

Printer-friendly Version

Interactive Discussion 


\section{Conclusion}

This paper describes a series of experiments, in a specially-designed structure, to test the physics of condensation and its potential to cause airflows. The results have provided data for a careful analysis of the physics involved, showing that condensation 5 and the subsequent release of kinetic energy from the partial pressure change do indeed account for the observed airflow. The experimental results therefore provide evidence that condensation and not buoyancy is the major mechanism driving airflow, thus lending strong support to one of the main tenets of the BPT.

The results are significant and unambiguous. At least at the laboratory scale, using only conventional physics, such as is employed in climatological studies, the primary force driving convection appears to be the kinetic energy released in the implosive events which take place during condensation, with a sudden reduction $->1200$-fold in the air volume of one gram-molecule of water vapour $(18 \mathrm{~g})$ as it transforms to liquid and ice. Air density changes are shown to be orders of magnitude less important in convection processes compared to partial pressure changes on condensation.

The macro-physics of the experiment is not fundamentally different from that in the lower atmosphere at large. The same laws apply and are widely used by hydrologists, meteorologists and climatologists. Those opposed to the biotic pump theory should therefore re-consider their position and take into account that the physics underlying the theory may not only be correct, but that it operates in the atmosphere at large.

The general implications are that the great forests of the world play a fundamental role in air mass circulation through providing water vapour via evapotranspiration, and are therefore the "fuel" for a high rate of cloud condensation. Airflow circulation is the net result, bringing the rain to the deep interior of continents. The Biotic Pump theory suggests that the hydrological role of rainforests is by far their most important climatic contribution, and that large-scale deforestation may well be as detrimental in its consequences for the well-being of the planet as are greenhouse gas emissions. Indeed, it may be that in macro-climatological terms whether forests are net absorbers
HESSD

12, 10921-10974, 2015

Experimental

evidence of

condensation-driven airflow

P. Bunyard et al.

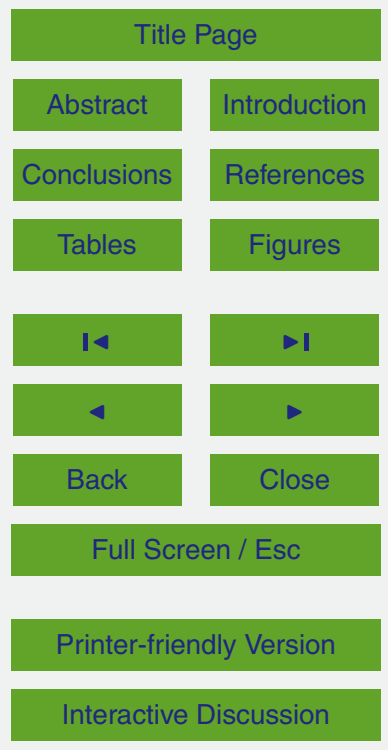


Acknowledgement. The experimental structure with its equipment and the actual experimentation made possible through the bounteous support from the Good Energies Foundation,

5 Switzerland. Thanks too to Jaymart Ltd for having provided the matting to cover the flooring of the structure. We are extremely grateful to Jon Tinker for his comments and suggestions in the preparation of this manuscript and to Francis Dufort for his help designing the structure.

\section{References}

Boyle, G.: Renewable Energy: Power for a Sustainable Future, Open University \& Oxford University Press, Oxford, UK, 1998.

Builes-Jaramillo, A. and Poveda, G.: Seasonal and Interannual Feedbacks between Tropical North Atlantic SST and Amazonian Hydroclimatology, in press, 2015.

Bunyard, P. P.: How the Biotic Pump links the hydrological cycle and the rainforest to climate: Is it for real? How can we prove it?, F. d. Publicaciones, Bogotá, Cundinamarca, Colombia, 15 University of Sergio Arboleda, 2014.

Bunyard, P., Netchev, P., Peña, C., and Redondo, J.: The Barometric Tidal Wave, What is it? STAHY 3rd International Conference on Hydrology, Tunis, 1-2 October 2012.

Makarieva, A. M. and Gorshkov, V. G.: Biotic pump of atmospheric moisture as driver of the hydrological cycle on land, Hydrol. Earth Syst. Sci., 11, 1013-1033, doi:10.5194/hess-11-

$20 \quad$ 1013-2007, 2007.

Makarieva, A. M. and Gorshkov, V. G.: Reply to A. G. C. A. Meesters et al.'s comment on "Biotic pump of atmospheric moisture as driver of the hydrological cycle on land", Hydrol. Earth Syst. Sci., 13, 1307-1311, doi:10.5194/hess-13-1307-2009, 2009.

Makarieva, A. M., Gorshkov, V. G., and Li, B.-L.: The key physical parameters governing frictional dissipation in a precipitating atmosphere, J. Atmos. Sci., 70, 2916-2929, 2013.

Makarieva, A. M., Gorshkov, V. G., Sheil, D., Nobre, A. D., and Li, B.-L.: Where do winds come from? A new theory on how water vapor condensation influences atmospheric pressure and dynamics, Atmos. Chem. Phys., 13, 1039-1056, doi:10.5194/acp-13-1039-2013, 2013.

Experimental

evidence of

condensation-driven

airflow

P. Bunyard et al.

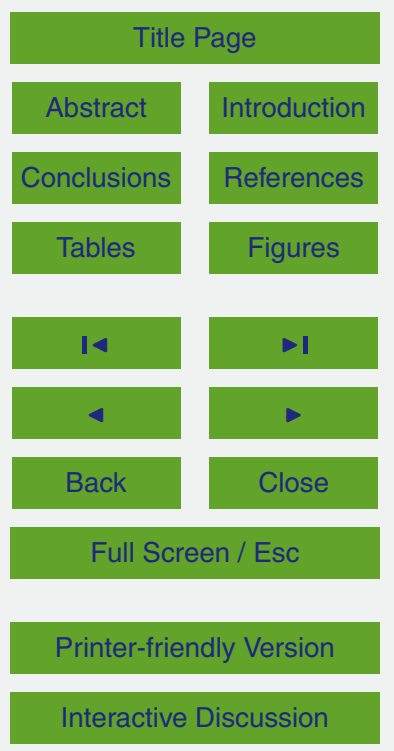


Makarieva, A. M., Gorshkov, V. G., Sheil, D., Nobre, A. D., Bunyard, P. P., and Li, B.-L.: Why does air passage over forest yield more rain? Examining the coupling between rainfall, pressure and atmospheric moisture content, J. Hydrometeorol., 15, 411-426, 2014.

Marengo, J. A.: On the hydrological cycle of the Amazon Basin: A historical review and current 5 state-of-the-art, Revista Brasileira de Meteorologia, 21, 1-19, 2006.

Mcllveen, R.: Fundamentals of Weather \& Climate, 2nd Edn., Oxford University Press, Oxford, 2010.

Meesters, A. G.: Comment on "Biotic pump of atmospheric moisture as driver of the hydrological cycle on land" by A. M. Makarieva and V. G. Gorshkov, Hydrol. Earth Syst. Sci., 11, 10131033, 2007,

http://www.hydrol-earth-syst-sci.net/11/1013/2007/., Hydrol.Earth Syst. Sci., 13, 1299-1305, 2009.

Poveda, G.: On the existence of Lloro (the rainiest locality on Earth): enhanced ocean-landatmosphere interaction by a low-level jet, Geophys. Res. Lett., 27, 1675-1678, 2000.

15 Poveda, G. L.: Seasonal precipitation patterns along pathways of South American low-level jets and aerial rivers, Water Resour. Res., 50, 98-118, 2014.

Salati, E.: The forest and the hydrological cycle, in: Geophysiology of Amazonia, edited by: Dickinson, R., Wiley \& Sons, New York, 273-296, 1987.

Spracklen, D. V., Arnold, S. R., and Taylor, C. M.: Observations of increased tropical rainfall preceded by air passage over forests, Nature, 489, 282-285, 2012.

HESSD

12, 10921-10974, 2015

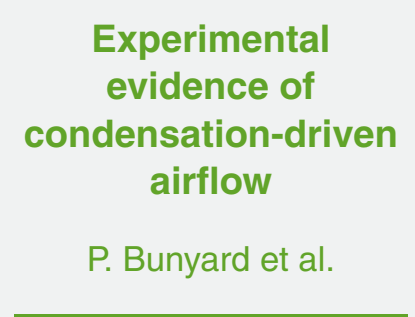

Title Page

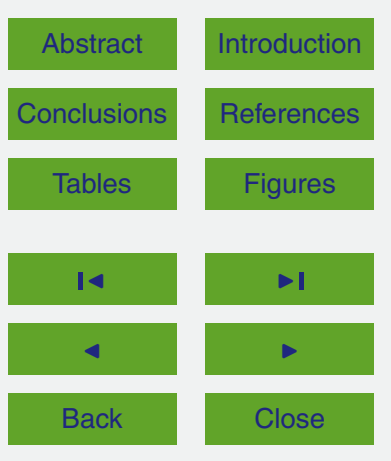

Full Screen / Esc

Printer-friendly Version

Interactive Discussion 
Table 1. Data from Experiments 1 to 4.

\begin{tabular}{|c|c|c|c|c|}
\hline Data & $\begin{array}{l}\text { Experiment } 1 \\
6 \text { August }\end{array}$ & $\begin{array}{l}\text { Experiment } 2 \\
22 \text { September }\end{array}$ & $\begin{array}{l}\text { Experiment } 3 \\
6 \text { March }\end{array}$ & $\begin{array}{l}\text { Experiment } 4 \\
17 \text { September }\end{array}$ \\
\hline Initial temperature & 20.09 & 13.69 & 7.51 & 20.18 \\
\hline Final temperature & 19.53 & 13.21 & 8 & 16.64 \\
\hline Initial $\mathrm{RH} \%$ & 73.93 & 90.54 & 97.49 & 31.15 \\
\hline Final $\mathrm{RH} \%$ & 63.21 & 75 & 92.15 & 47.12 \\
\hline Rate change $r, \mathrm{~kg} \mathrm{~kg}^{-1}$ dry air at $1000 \mathrm{~s}$ & 0.00006535 & 0.0000567 & 0.000034206 & 0.00003196 \\
\hline Airflow, $\mathrm{m} \mathrm{s}^{-1}$ clockwise + counter & $0.1+0.09=0.19$ & 0.18 & $0.06+0.02=0.08$ & 0.14 \\
\hline Initial air moisture $\mathrm{g} \mathrm{m}^{-3}$ air & 15.95 & 13.89 & 7.614 & 7.14 \\
\hline Final moisture $\mathrm{g} \mathrm{m}^{-3}$ air & 13.91 & 11.12 & 7.74 & 8.33 \\
\hline Collected rainfall & 40 & 25 & 0 & 3 \\
\hline Calculated rainfall & 41.4 & 24.26 & -7 & 1.19 \\
\hline KE at $1000 \mathrm{~s}$ rate change ppwv in Ws & 10.23 & 8.835 & 4.866 & 4.271 \\
\hline KE at $1000 \mathrm{~s}$ air density rate change in Ws & 0.00083 & 0.000663 & 0.0006497 & 0.0008779 \\
\hline Ratio of KE & 12327 & 13334 & 7490 & 4865 \\
\hline
\end{tabular}

\section{HESSD}

12, 10921-10974, 2015

\section{Experimental \\ evidence of}

condensation-driven airflow

\section{P. Bunyard et al.}

Title Page

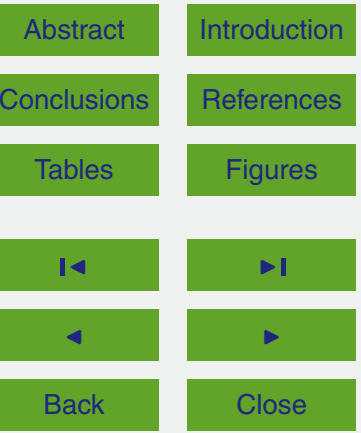

Full Screen / Esc

Printer-friendly Version

Interactive Discussion 


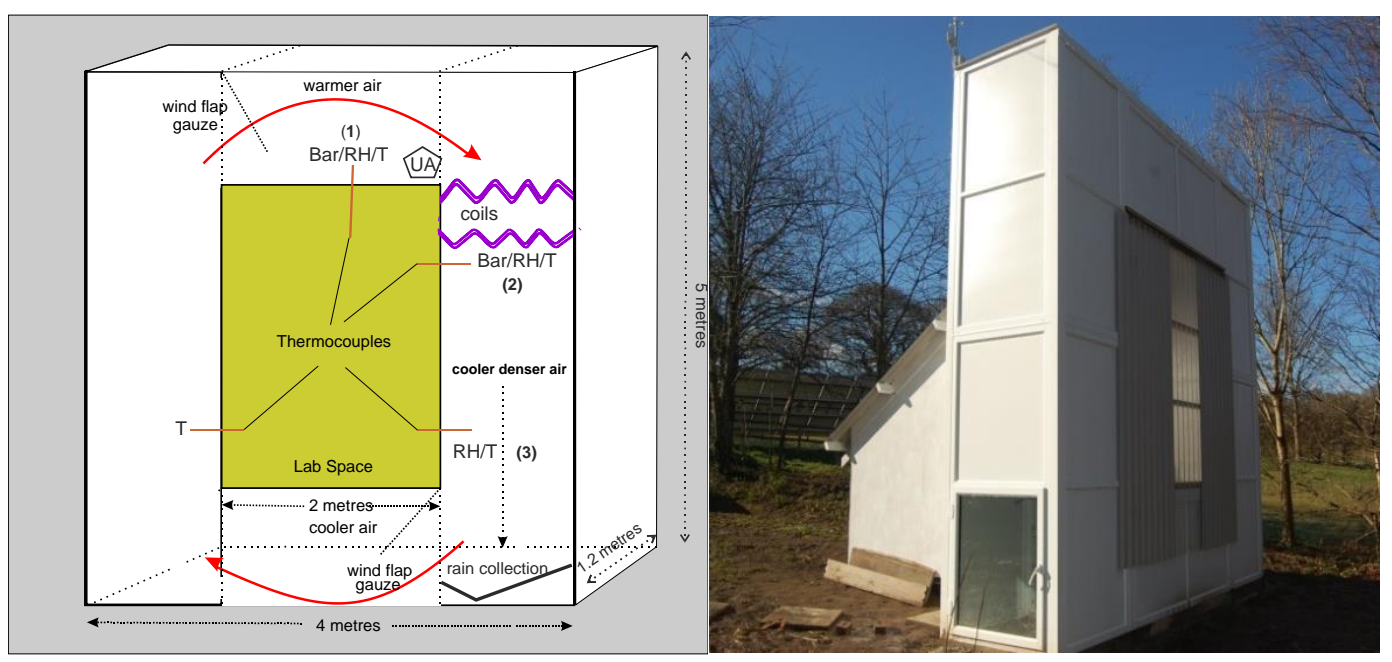

Figure 1. The experimental structure, showing diagrammatically the positioning of the sensors, Barometer (BAR), Relative Humidity Hygrometer (RH), Thermocouple (T), 2-D Ultrasonic Anemometer (UA), the refrigeration coils (Coils) and the rain-collector. Sensors for $\mathrm{RH}$ and $\mathrm{T}$ have been placed at each of the three locations, numbered (1) (2) and (3), and BAR at locations (1) and (2). The air is captured from the outside air at the beginning of each experiment. Changes in temperature, relative humidity and barometric pressure depend on artificial refrigeration from the cooling tubes and to an extent, not measured, from the impact of external wind and insolation upon the insulated (PVC) structure.

\section{HESSD}

12, 10921-10974, 2015

\section{Experimental \\ evidence of \\ condensation-driven airflow}

P. Bunyard et al.

Title Page

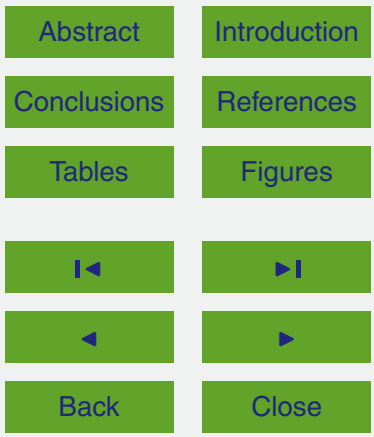

Full Screen / Esc

Printer-friendly Version

Interactive Discussion 


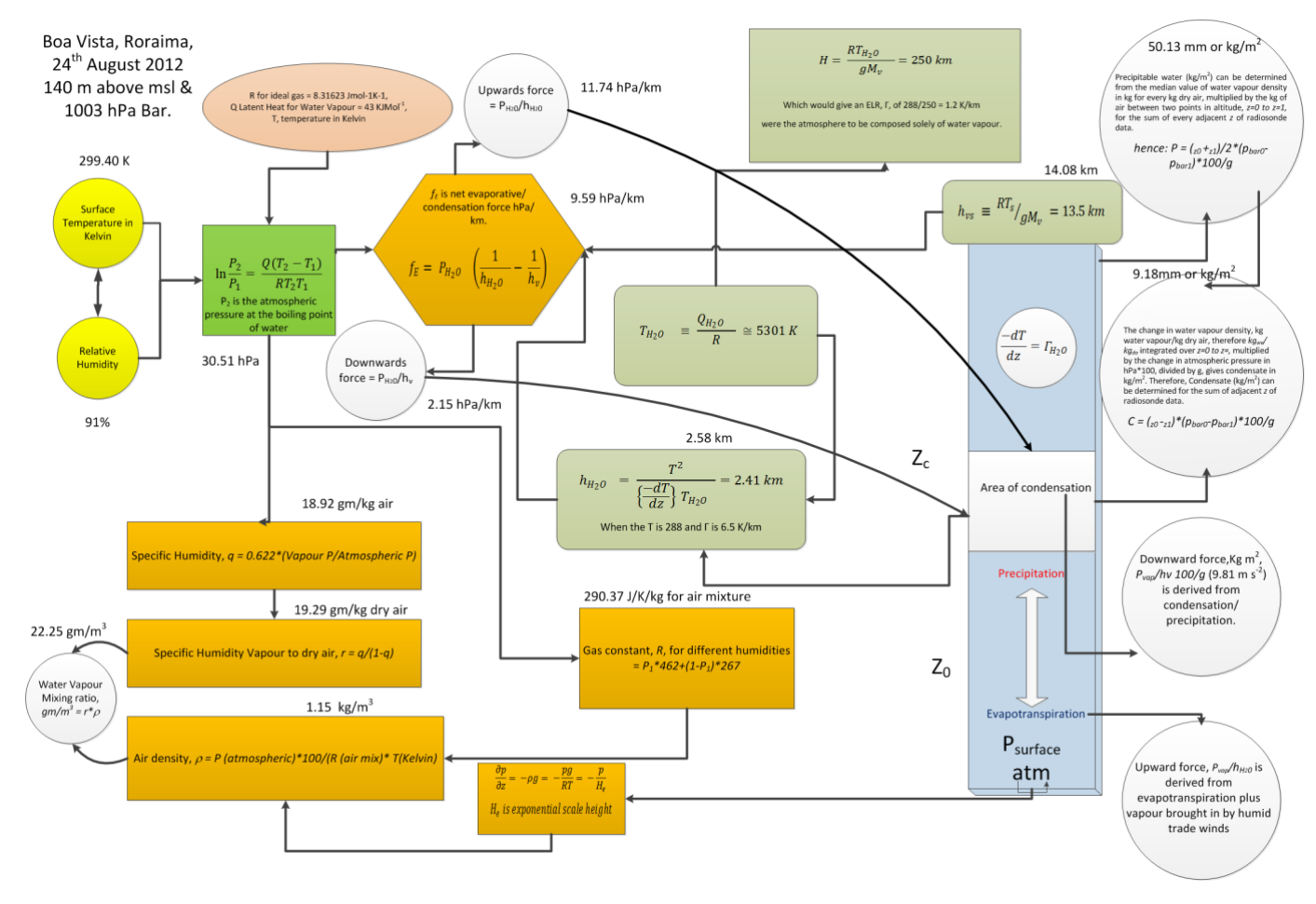

Figure 2. A flow chart (Bunyard, 2014), displaying the physics used in the experiment and in handling radiosounding data as for 24 August 2012; Boa Vista, Roraima, Brazil.

\section{HESSD}

12, 10921-10974, 2015

\section{Experimental \\ evidence of}

condensation-driven airflow

P. Bunyard et al.

Title Page

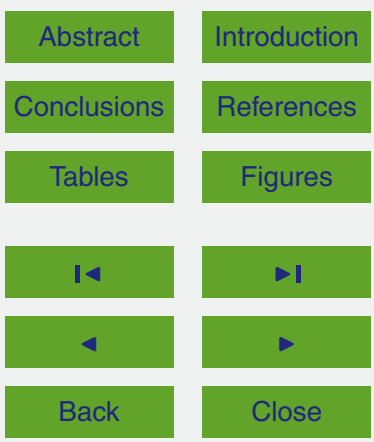

Full Screen / Esc

Printer-friendly Version

Interactive Discussion 


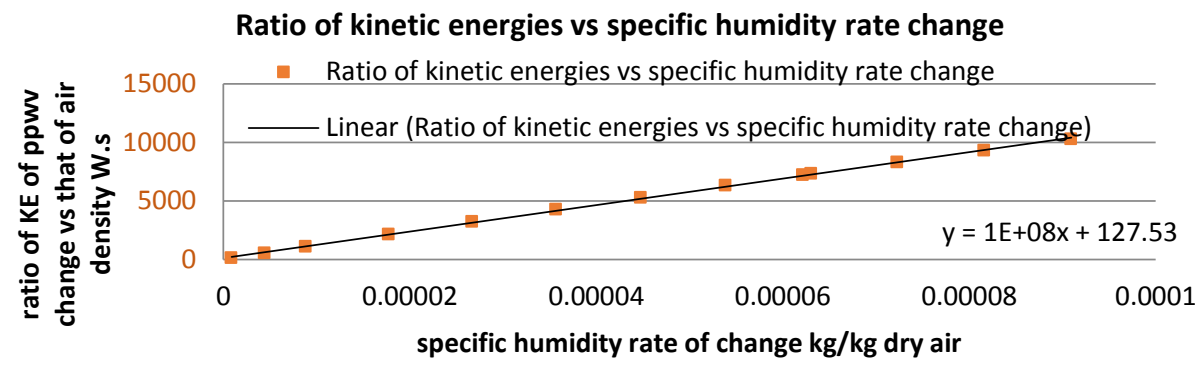

Figure 3. Ratio of kinetic energy of partial pressure change (ppwv) to that of air density change, both converted to Ws, as the initial humidity in the experimental structure is theoretically reduced from $100 \% \mathrm{RH}$ (relative humidity) to $1 \%$. The $y$ axis gives the derived ratio of the kinetic energies in Ws and the $x$ axis indicates the rate at which the specific humidity reduces because of condensation in $\mathrm{kg}$ of water vapour change per kg dry air (r).

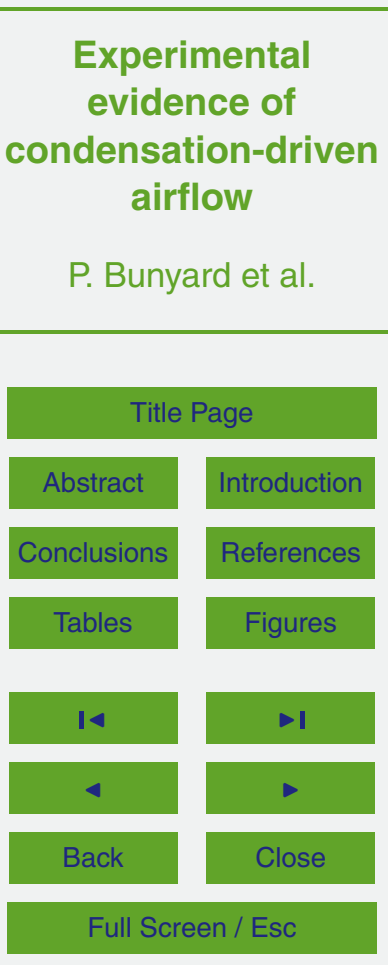

Printer-friendly Version

Interactive Discussion 


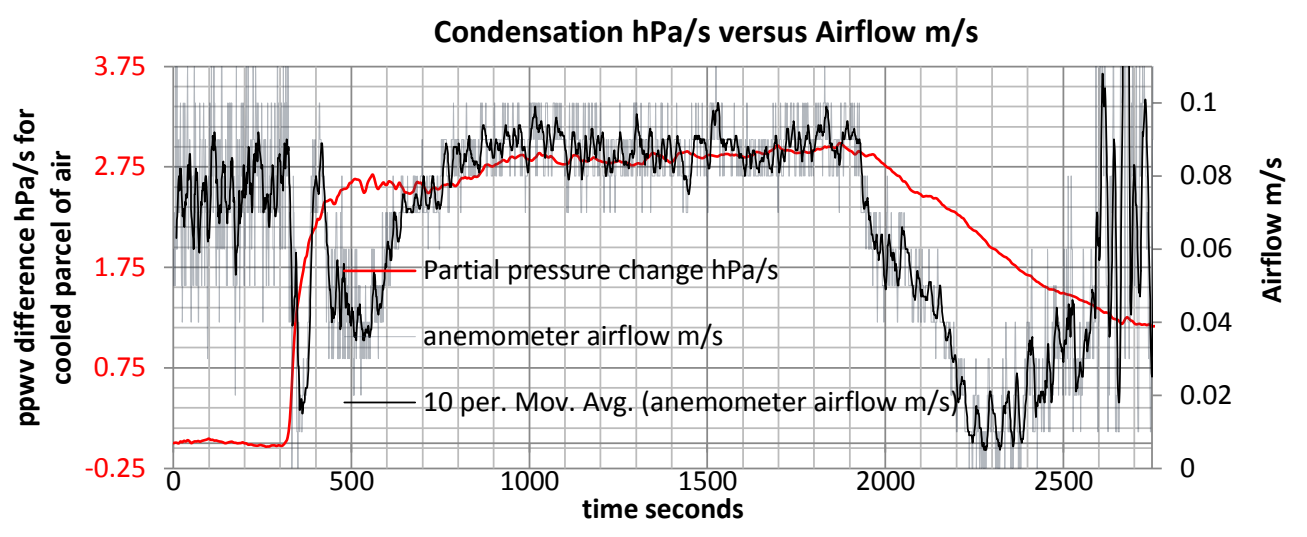

Figure 4. Experiment 1 (6 August 2015). Profile of condensate change hPa s${ }^{-1}$ (red and left $y$ axis) and airflow $\mathrm{m} \mathrm{s}^{-1}$ (black right $y$ axis). The airflow before the compressor is switched on and when switched off is the result of external differential heating (insolation) of the two columns. The flow from that heating is counter-clockwise and once the compressor is switched on the directionality of the airflow changes abruptly to clockwise as seen in, with a change from 360 to $180^{\circ}$. The clockwise airflow from the condensation therefore competes against default the counter-clockwise flow from differential exposure of the structure to sunlight. The resultant airflow during condensation is $<0.1 \mathrm{~m} \mathrm{~s}^{-1}$. The airflow noise is reduced through displaying the flow with a $10 \mathrm{~s}$ moving average.

\section{Experimental \\ evidence of \\ condensation-driven airflow \\ P. Bunyard et al.}

Title Page

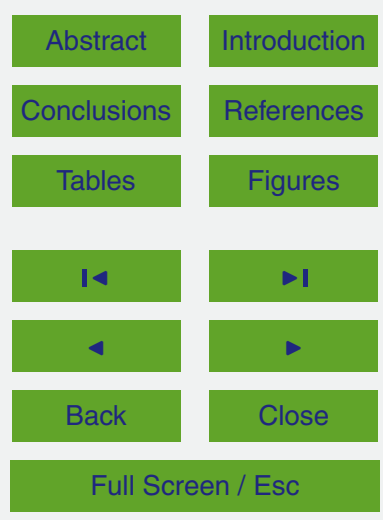

Printer-friendly Version

Interactive Discussion 


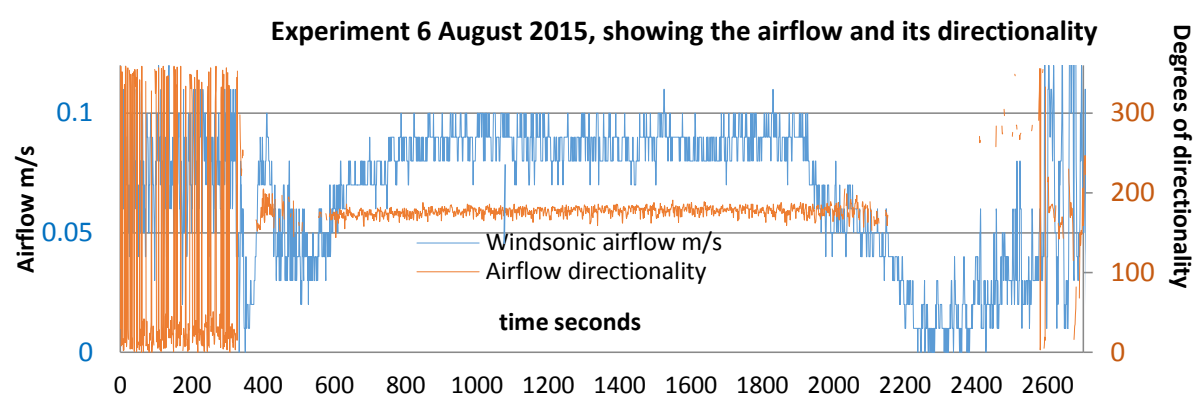

Figure 5. Experiment 1 (6 August 2015). Anemometer reading $\mathrm{m} \mathrm{s}^{-1}$ with directionality. The central section, from 600 to $2000 \mathrm{~s}$, when the compressor is switched on, shows a directionality of $180^{\circ}$, such that the flow is clockwise. Before switching on the condenser and equally after switching it off, the airflow, with directionality circa $360^{\circ}$, is counter-clockwise. During the course of the experiment, the changing directionality is evidence that condensation of a parcel of air, 400 times smaller in volume than the total enclosed air volume, can overcome the counterclockwise circulation derived from the high summer insolation of the right-hand column. See Fig. 4 for the correspondence between condensation and airflow.

\section{Experimental \\ evidence of \\ condensation-driven airflow \\ P. Bunyard et al.}

Title Page

Abstract Introduction

Conclusions References

Tables Figures

14

4

Back

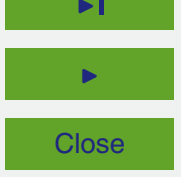

Full Screen / Esc

Printer-friendly Version

Interactive Discussion 


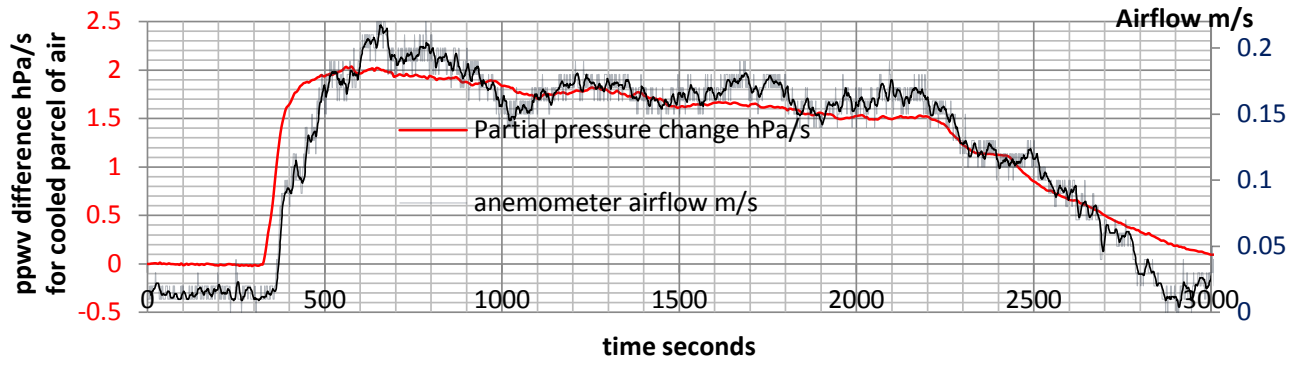

Figure 6. Experiment 2 (22 September 2015): partial pressure change vs. airflow. The compressor is switched on at $300 \mathrm{~s}$ and switched off at $2200 \mathrm{~s}$. The airflow velocity declines during the time of condensation as does the rate of condensation owing to the reduction in absolute humidity. The airflow "noise" is reduced by averaging the flow over a moving $10 \mathrm{~s}$ period.

\section{HESSD}

12, 10921-10974, 2015

\section{Experimental \\ evidence of}

condensation-driven airflow

\section{P. Bunyard et al.}

Title Page

Abstract

Introduction

Conclusions

References

Tables

Figures

14

Back

Close

Full Screen / Esc

Printer-friendly Version

Interactive Discussion 


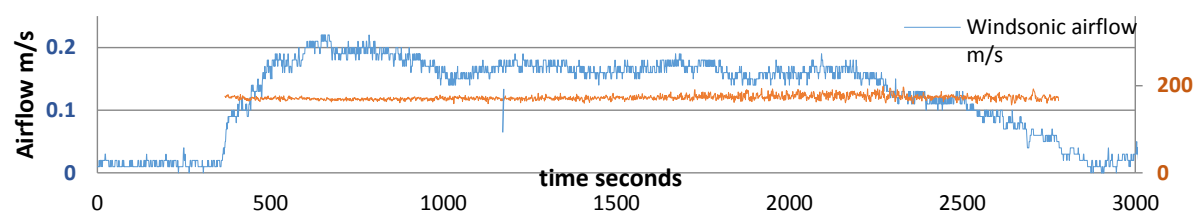

Figure 7. Experiment 2 (22 September 2015). Airflow and directionality. See Fig. 6 for the correspondence between airflow induced by condensation and the change in partial pressure of water vapour $\left(\mathrm{hPa} \mathrm{s}^{-1}\right)$. In comparison with the airflow in Experiment 1, the airflow in Experiment 2 exceeds $0.2 \mathrm{~m}$, even though the initial starting conditions are similar in both experiments. Airflow is blue, directionality showing clockwise movement is brown.

\section{HESSD}

12, 10921-10974, 2015

\section{Experimental \\ evidence of \\ condensation-driven airflow}

\section{P. Bunyard et al.}

Title Page

Abstract

Introduction

Conclusions

References

Tables

Figures

14

Back

Close

Full Screen / Esc

Printer-friendly Version

Interactive Discussion 


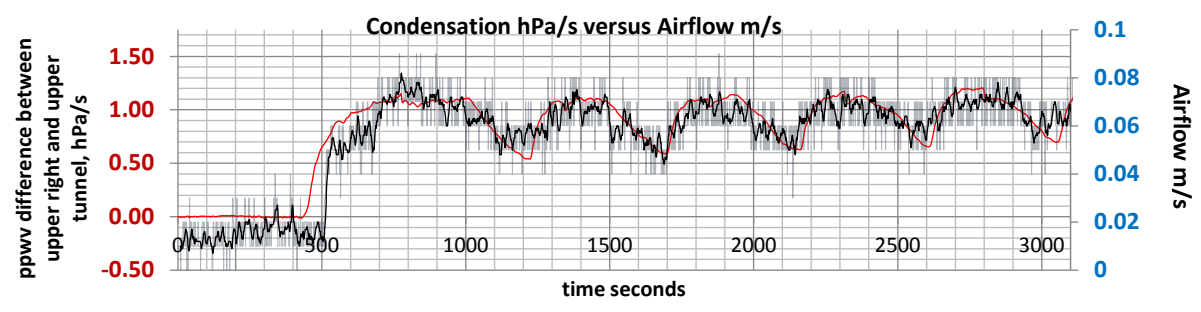

Figure 8. Experiment 3 (6 March 2015). The profile of the inverse change in the partial pressure of water vapour, $\mathrm{hPa} \mathrm{s}^{-1}$ (red) shows the peaks corresponding with peaks in the airflow $\mathrm{m} \mathrm{s}^{-1}$ (blue). During this experiment, because of external low temperatures $\left(<8^{\circ} \mathrm{C}\right)$ the compressor thermostat automatically switched the refrigeration on and off.

\section{HESSD}

12, 10921-10974, 2015

\section{Experimental \\ evidence of}

condensation-driven airflow

\section{P. Bunyard et al.}

Title Page

Abstract

Introduction

Conclusions

References

Tables

Figures

14

Back

Close

Full Screen / Esc

Printer-friendly Version

Interactive Discussion 


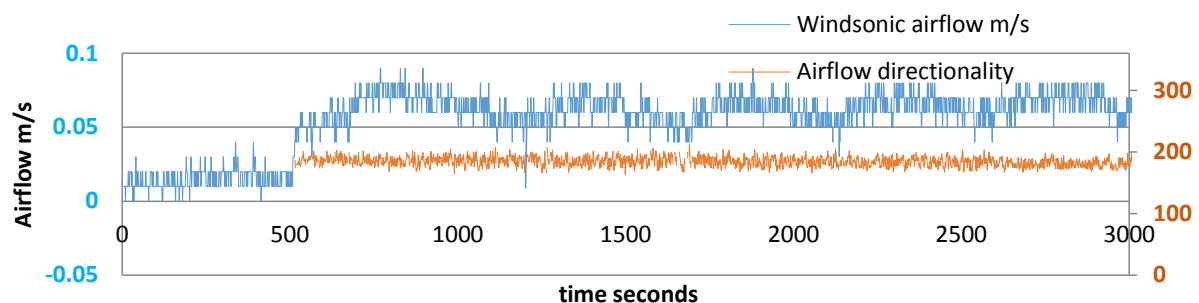

Figure 9. Experiment 3 (6 March 2015). The low external temperatures lead to pulsing of the thermostatically controlled compressor. As seen in Fig. 8, the pulsing of the compressor corresponds precisely to airflow (blue). The directionality (brown) is clockwise.

\section{HESSD}

12, 10921-10974, 2015

\section{Experimental \\ evidence of}

condensation-driven airflow

\section{P. Bunyard et al.}

Title Page

Abstract

Introduction

Conclusions

References

Tables

Figures

14

Back

Close

Full Screen / Esc

Printer-friendly Version

Interactive Discussion 


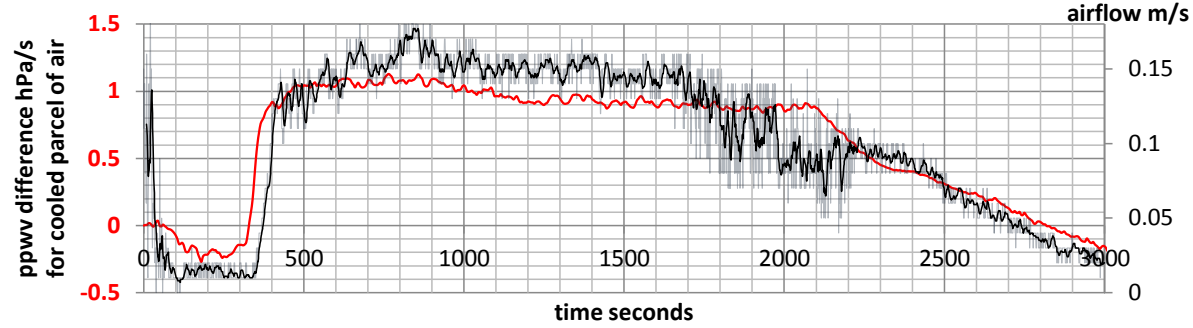

Figure 10. Experiment 4 (17 September 2015). A dehumidifier was used prior to the experiment to bring the relative humidity down below $40 \%$. The airflow during the period of cooling, from 300 to $2000 \mathrm{~s}$, was reduced to approximately $0.15 \mathrm{~m} \mathrm{~s}^{-1}$, indicating that the airflow responded to the reduction in the rate of change of the partial pressure of water vapour.

\section{HESSD}

12, 10921-10974, 2015

\section{Experimental evidence of}

condensation-driven airflow

\section{P. Bunyard et al.}

Title Page

Abstract

Introduction

Conclusions

References

Tables

Figures

14

Back

Close

Full Screen / Esc

Printer-friendly Version

Interactive Discussion 


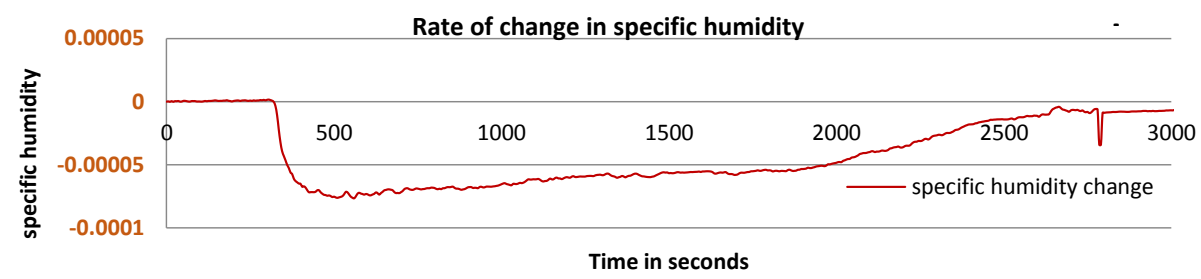

Figure 11. Experiment 1 (6 August 2015). The cooling begins at $300 \mathrm{~s}$ and finishes at $1850 \mathrm{~s}$. The rate of change in the specific (absolute) humidity reduces sharply in the parcel of air passing over the cooling coils at the switching on of the compressor (hence showing a "drying of the air") but begins to rise during the time during which cooling takes place (showing that the rate of "drying" is declining). Once the compressor is switched off the temperature rises and the rate of change in the specific humidity in the parcel of air begins to approach zero, as it was at the beginning of the experiment. At $1000 \mathrm{~s}$ the rate of change in the specific humidity $r$ is $-0.00006535 \mathrm{~kg}$ of water vapour per $\mathrm{kg}$ dry air.

\section{HESSD}

$12,10921-10974,2015$

\section{Experimental \\ evidence of}

condensation-driven airflow

\section{P. Bunyard et al.}

\section{Title Page}

Abstract Introduction

Conclusions References

Tables Figures

14$$
\triangleleft
$$

Back

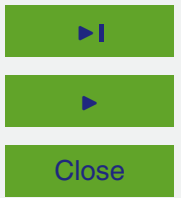

Full Screen / Esc

Printer-friendly Version

Interactive Discussion 


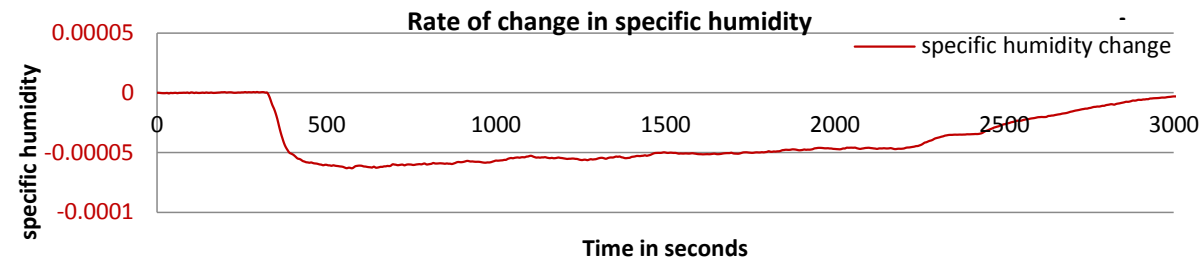

Figure 12. Experiment 2 (22 September 2015). The rate of change in the specific (absolute) humidity reduces sharply in the parcel of air passing over the cooling coils at the switching on of the compressor. At $1000 \mathrm{~s}$ the rate of change in specific humidity $r$ is $-0.000056677 \mathrm{~kg}$ of water vapour per $\mathrm{kg}$ dry air.

\section{HESSD}

12, 10921-10974, 2015

\section{Experimental}

evidence of

condensation-driven airflow

\section{P. Bunyard et al.}

Title Page

Abstract

Introduction

Conclusions

References

Tables

Figures

14

Back

Close

Full Screen / Esc

Printer-friendly Version

Interactive Discussion 


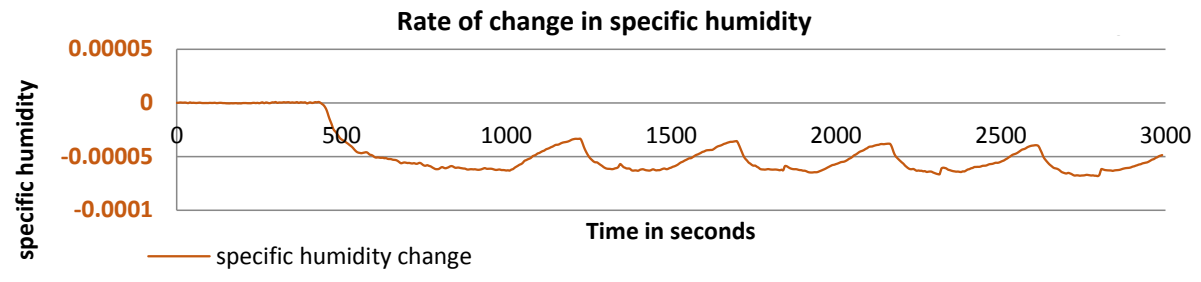

Figure 13. Experiment 3 (6 March 2015). The pulsing changes in the rate of change in specific humidity, $r$, reflect the thermostatically controlled switching on and off of the compressor. In this experiment, the rate of change of $r$ in the parcel of air at $1000 \mathrm{~s}$ is $-0.000063111 \mathrm{~kg}$ water vapour per kg dry air. At $1200 \mathrm{~s}$ the change in $r$ is $-0.0000342 \mathrm{~kg}$ water vapour per $\mathrm{kg}$ dry air and the measured airflow is $0.05 \mathrm{~m} \mathrm{~s}^{-1}$.

\section{HESSD}

12, 10921-10974, 2015

\section{Experimental \\ evidence of}

condensation-driven

airflow

\section{P. Bunyard et al.}

Title Page

Abstract

Introduction

Conclusions

References

Tables

Figures

14

Back

Close

Full Screen / Esc

Printer-friendly Version

Interactive Discussion 


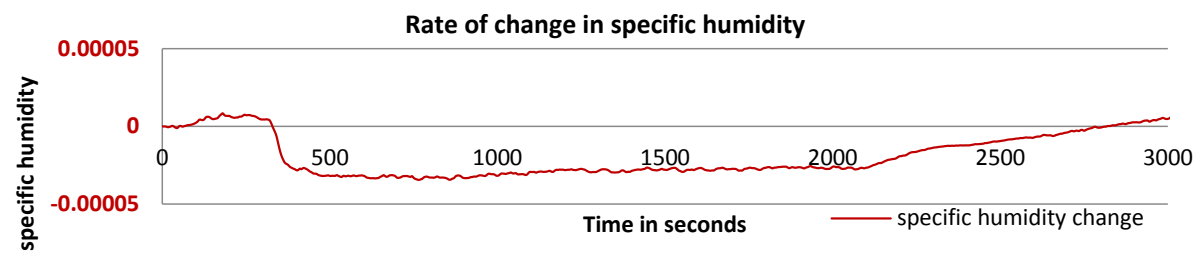

Figure 14. Experiment 4 (17 September 2015). The dehumidifer has reduced the relative humidity to below $40 \%$ and, despite initial temperatures $>20^{\circ} \mathrm{C}$, the change to $r$ in the cooled parcel of air at $1000 \mathrm{~s}$ is reduced to $-0.00003189 \mathrm{~kg} \mathrm{~kg}^{-1}$ dry air.

\section{HESSD}

12, 10921-10974, 2015

\section{Experimental}

evidence of

condensation-driven airflow

\section{P. Bunyard et al.}

Title Page

Abstract

Introduction

Conclusions

References

Tables

Figures

14

Back

Close

Full Screen / Esc

Printer-friendly Version

Interactive Discussion 


\section{HESSD}

12, 10921-10974, 2015

\section{Experimental \\ evidence of}

condensation-driven airflow

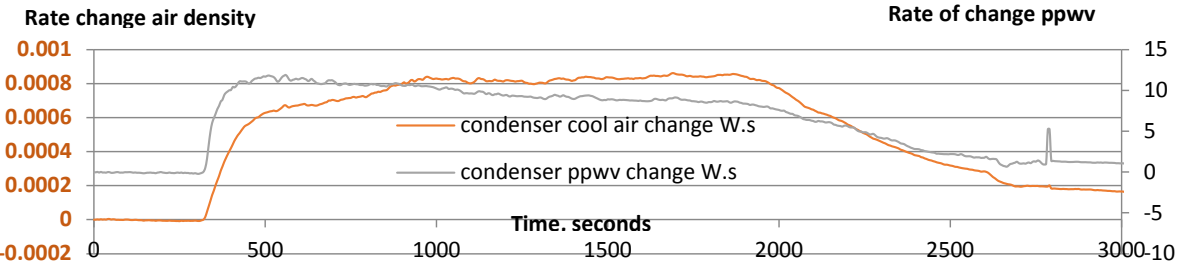

P. Bunyard et al.

Title Page

Figure 15. Experiment 1 (6 August 2015). Left-hand $y$ axis is the air density change $\mathrm{s}^{-1}$ in Ws of a parcel of air as it passes through the condenser (brown). The right-hand $y$ axis is the partial pressure change Ws of the same parcel (grey) as it passes from the upper tunnel into the condenser. At $1000 \mathrm{~s}$ the ratio between the air density change in Ws and the partial pressure change in Ws is 14933.

14

Back

Full Screen / Esc

Printer-friendly Version

Interactive Discussion 


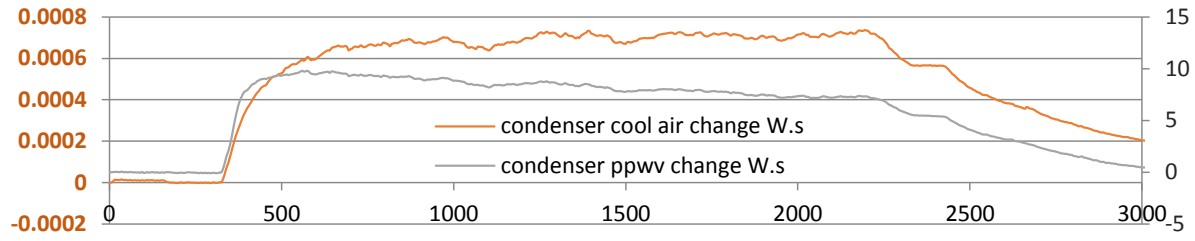

Figure 16. Experiment 2 (22 September 2015). The respective kinetic energy of the rate of change in water vapour partial pressure and of air density in the same parcel of air. At $1000 \mathrm{~s}$ the ratio between the two curves is 13333 .

\section{HESSD}

12, 10921-10974, 2015

\section{Experimental \\ evidence of}

condensation-driven airflow

\section{P. Bunyard et al.}

Title Page

Abstract

Introduction

Conclusions

References

Tables

Figures

14

Back

Close

Full Screen / Esc

Printer-friendly Version

Interactive Discussion 


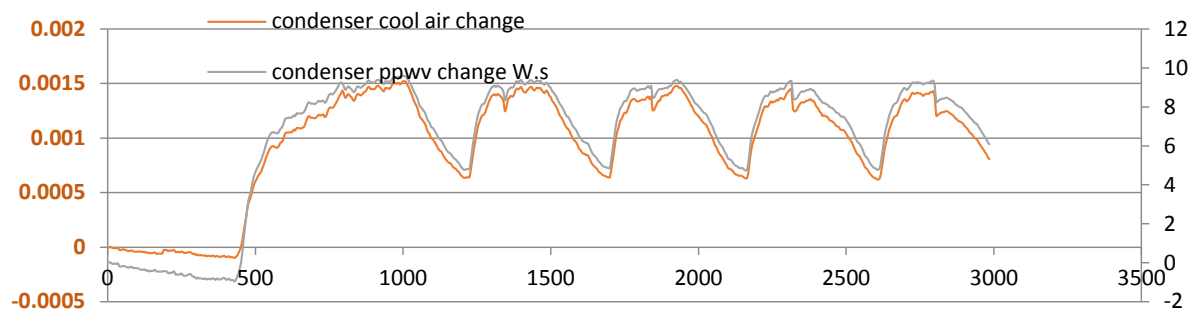

Figure 17. Experiment 3 ( 6 March 2015). The ratio at $1000 \mathrm{~s}$ between the kinetic energy of the partial pressure change (right-hand $y$ axis) vs. the air density change (left-hand $y$ axis) is 6544 .

\section{HESSD}

12, 10921-10974, 2015

Experimental

evidence of

condensation-driven airflow

\section{P. Bunyard et al.}

Title Page

Abstract

Introduction

Conclusions

References

Tables

Figures

14

Back

Close

Full Screen / Esc

Printer-friendly Version

Interactive Discussion 


\section{HESSD}

12, 10921-10974, 2015

\section{Experimental \\ evidence of}

condensation-driven airflow

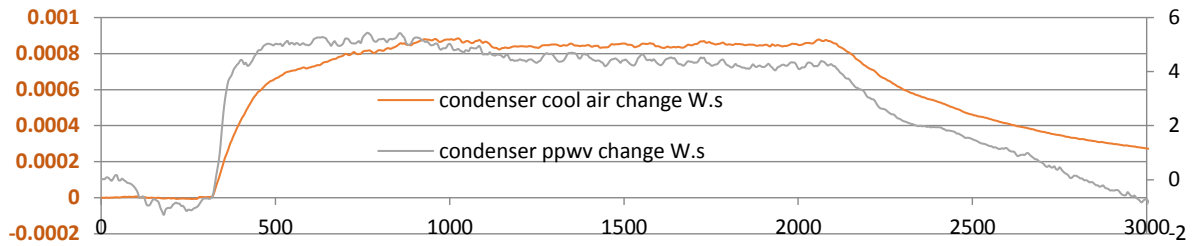

P. Bunyard et al.

Figure 18. Experiment 4 (17 September 2015). The initial reduction in $\mathrm{RH}$ to below $40 \%$ has led to a ratio of 4865 for the respective kinetic energies of air density change and of water vapour partial pressure change. That decline in the ratio compared to that calculated in Figs. 15 and 16 fits the theoretical reduction (Fig. 3 ) in the ratio as the relative humidity declines in the enclosed air.

Title Page

\section{Full Screen / Esc}

Printer-friendly Version

Interactive Discussion 


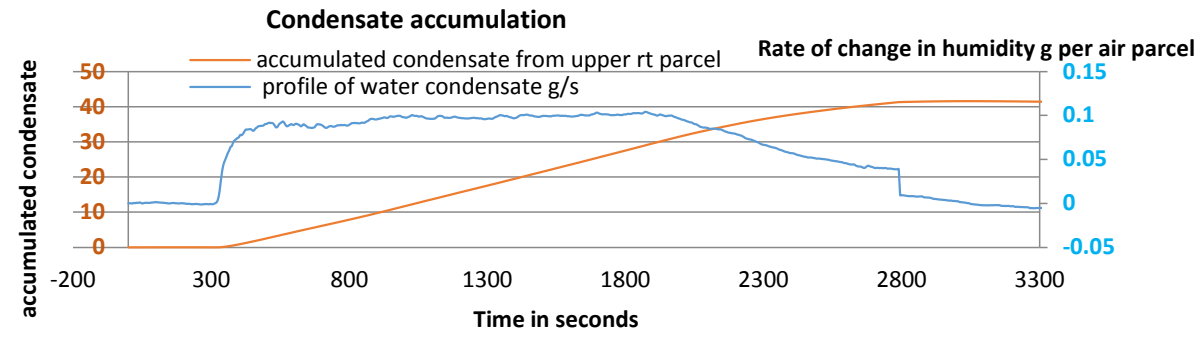

Figure 19. Experiment 1 (6 August 2015). The condensate accumulates as an ice-coating on the cooling coils during the course of the cooling. Through the application of Eqs. (1)-(8) the change in the air humidity in each parcel of air can be calculated (grams per second and grams total). At $3000 \mathrm{~s}(50 \mathrm{~min})$ the total accumulated is 41.57 . That collected as rain amounted to $40 \mathrm{~g}$. The left hand $y$ axis (brown) denotes the accumulated ice and the right-hand $y$ axis (blue) the inverse profile of the change in condensate.

\section{HESSD}

12, 10921-10974, 2015

\section{Experimental \\ evidence of}

condensation-driven airflow

\section{P. Bunyard et al.}

Title Page 


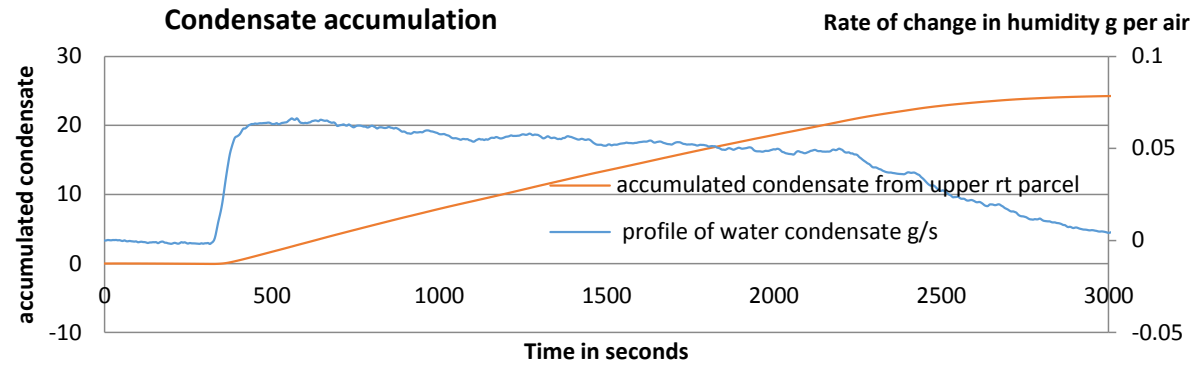

Figure 20. Experiment 2 (22 September 2015). The condensate accumulates as an ice-coating on the cooling coils during the course of the cooling. Through the application of Eqs. (1)-(8) the change in the air humidity in each parcel of air can be calculated (grams per second and grams total). At $3000 \mathrm{~s}(50 \mathrm{~min})$ the total accumulated is 24.26 . That collected as rain amounted to $25 \mathrm{~g}$. The left hand $y$ axis (brown) denotes the accumulated ice and the right-hand $y$ axis (blue) the inverse profile of the change in condensate.
HESSD

12, 10921-10974, 2015

\section{Experimental \\ evidence of}

condensation-driven airflow

P. Bunyard et al.

Title Page

Abstract

Introduction

Conclusions

References

Tables

Figures

14

Back

Close

Full Screen / Esc

Printer-friendly Version

Interactive Discussion 


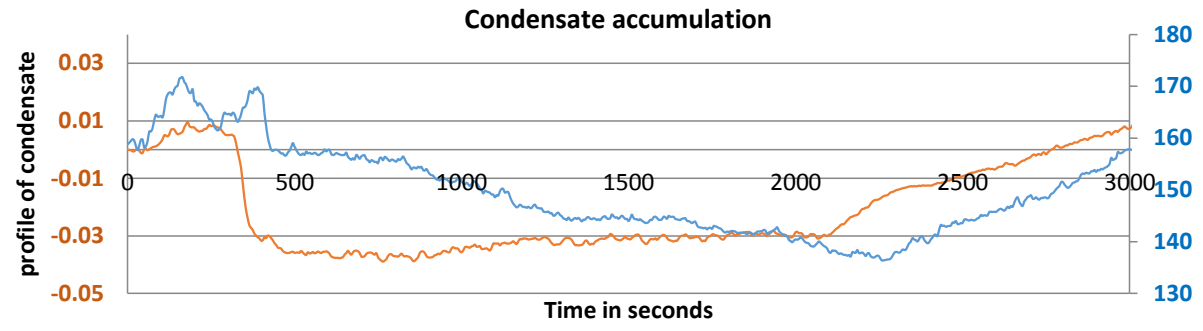

Figure 21. Experiment 4 (17 September 2015). The condensate in the total enclosed air (blue) compared to the change in the air from each cooled parcel (brown). By the end of the experiment $(3000 \mathrm{~s})$ the total moisture in the enclosed volume of air is close to that at the commencement of the experiment, indicating that ice-condensate has ablated. The rainfall collected amounted to $3 \mathrm{~g}$ and that calculated to $1.19 \mathrm{~g}$.

\section{HESSD}

12, 10921-10974, 2015

\section{Experimental \\ evidence of}

condensation-driven airflow

\section{P. Bunyard et al.}

Title Page

Abstract

Introduction

Conclusions

References

Tables

Figures

14

Back

Close

Full Screen / Esc

Printer-friendly Version

Interactive Discussion 


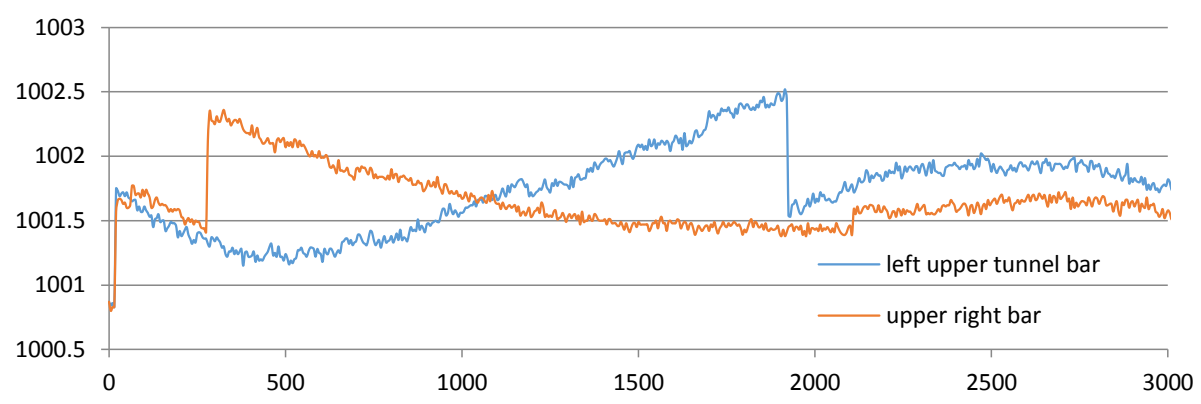

\section{HESSD}

12, 10921-10974, 2015

\section{Experimental \\ evidence of}

condensation-driven airflow

\section{P. Bunyard et al.}

Title Page

Figure 22. Experiment 4 (17 September 2015). Barometric pressure, hPa, in upper tunnel (before the flow to the coils) (blue) and at the point of cooling (brown). The Bar sensor (No. 2 Fig. 1, brown) shows a reduction in pressure of approximately $1 \mathrm{hPa}$ during the time of cooling. The Bar sensor in the upper tunnel (No. 2, Fig. 1 blue), and upstream of the airflow shows an increase in pressure of approximately $1 \mathrm{hPa}$ during the cooling period.

14

Back

Full Screen / Esc

Printer-friendly Version

Interactive Discussion 


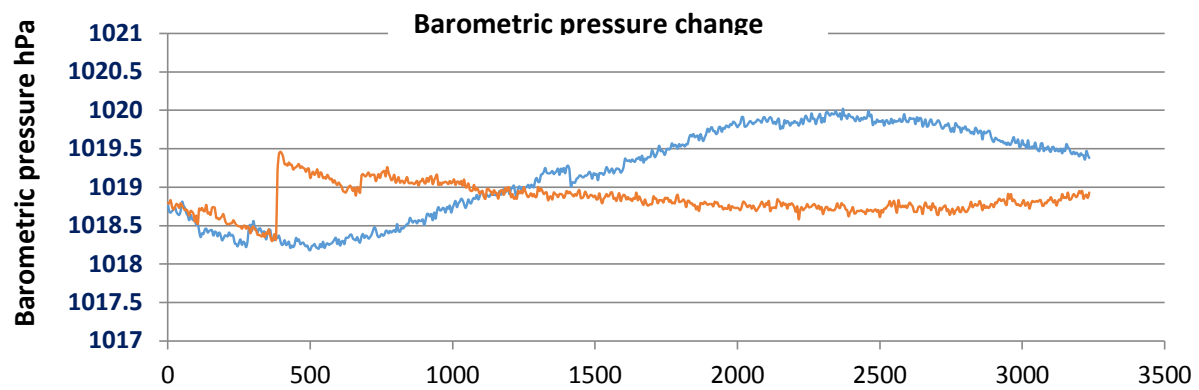

\section{HESSD}

12, 10921-10974, 2015

\section{Experimental \\ evidence of}

condensation-driven airflow

\section{P. Bunyard et al.}

Title Page

Figure 23. Experiment 1. Barometric pressures, $\mathrm{hPa}$ and partial pressure rate change $\mathrm{hPa}$ $\mathrm{s}^{-1}$. The Bar sensor (No. 2 Fig. 1, brown) shows a reduction in pressure of approximately $1 \mathrm{hPa}$ during the time of cooling. The Bar sensor in the upper tunnel (No. 2, Fig. 1 blue), and upstream of the airflow shows an increase in pressure of approximately $2 \mathrm{hPa}$ during the cooling period. That increase in pressure fits the pattern of cooler, denser, less moist air. 


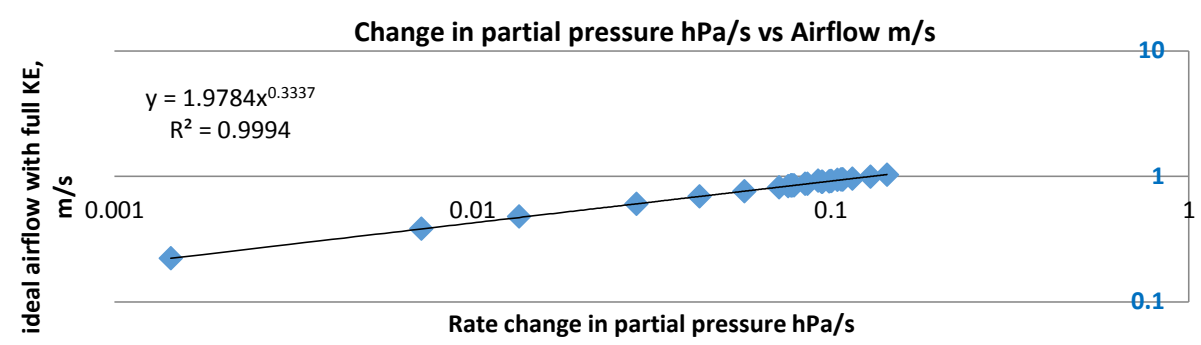

Figure 24. The theoretical airflow resulting from measured rate changes to the reduction in the partial pressure of water vapour $\left(\mathrm{hPas}^{-1}\right)$ as a result of condensation (blue). The partial pressure change $\mathrm{hPa} \mathrm{s}^{-1}$ is from location 2, Both the $x$ and $y$ axis are in a logarithmic scale to base 10 .

\section{HESSD}

12, 10921-10974, 2015

\section{Experimental \\ evidence of}

condensation-driven airflow

\section{P. Bunyard et al.}

Title Page

Abstract

Introduction

Conclusions

References

Tables

Figures

14

Back

Close

Full Screen / Esc

Printer-friendly Version

Interactive Discussion 


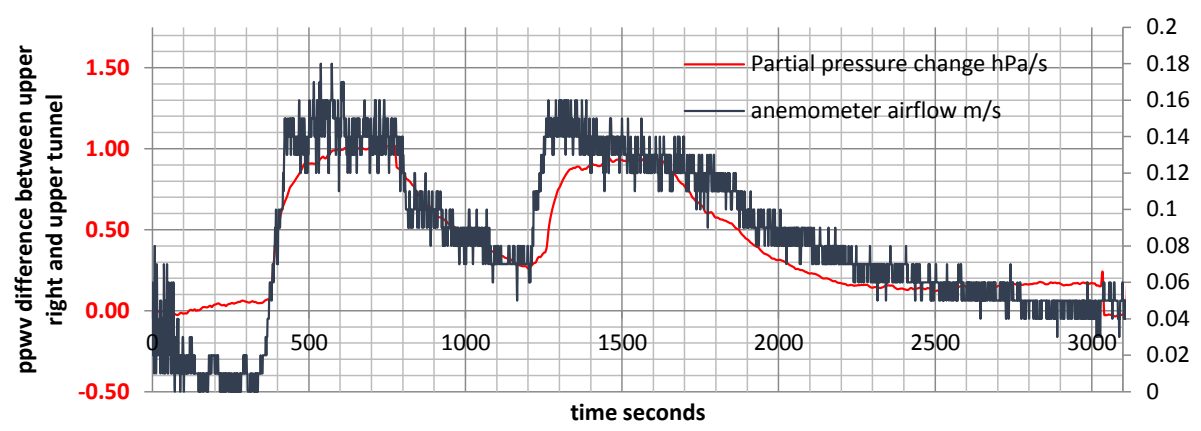

Figure 25. Experiment (1 March 2015). The partial pressure change (red) is indicated on the left-hand $y$ axis and the actual airflow (blue) on the right-hand $y$ axis. The resulting curves should be compared with Fig. 26 in which the partial pressure change is converted into airflow. The ideal airflow is some 5 times greater than the actual airflow. The compressor was switched on at $300 \mathrm{~s}$, off at $800 \mathrm{~s}$ and on again at $1200 \mathrm{~s}$ to be switched off finally at $1600 \mathrm{~s}$.

\section{HESSD}

12, 10921-10974, 2015

\section{Experimental \\ evidence of}

condensation-driven airflow

\section{P. Bunyard et al.}

Title Page

Abstract

Introduction

Conclusions

References

Tables

Figures

14

4

Back

Close

Printer-friendly Version

Interactive Discussion 


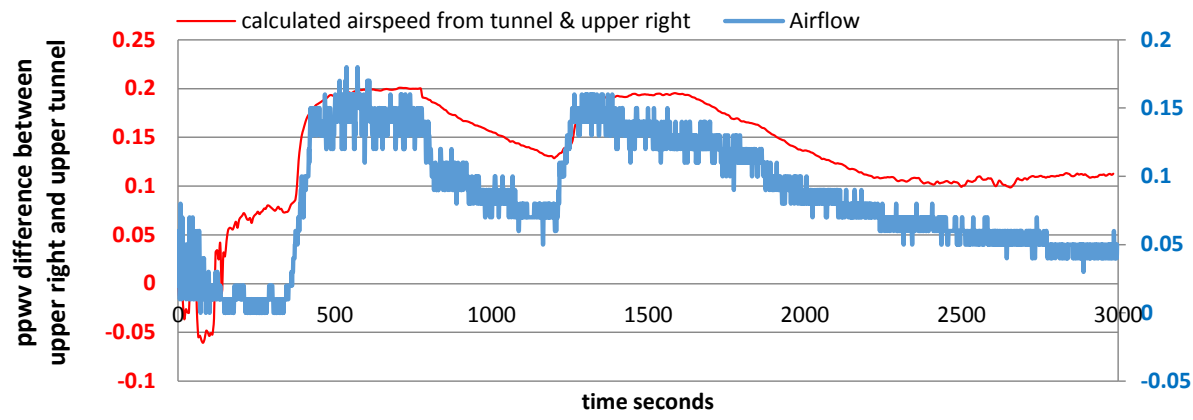

HESSD

12, 10921-10974, 2015

\section{Experimental \\ evidence of}

condensation-driven airflow

P. Bunyard et al.

Title Page

Abstract

Introduction

Conclusions

References

Tables

Figures

Figure 26. Calculated ideal airflow/5 (red) and actual airflow for 1 March 2015 (blue). Left axis calculated airflow, right axis the actual measured airflow and $x$ axis the time in seconds. Counter flow at the beginning of the experiment was equal to $0.03 \mathrm{~m} \mathrm{~s}^{-1}$ and should be added to the actual flow measured during condensation of 0.15 , thereby totalling $0.18 \mathrm{~m} \mathrm{~s}^{-1}$. The ideal calculated flow, divided by 5 gives a velocity of $0.2 \mathrm{~m} \mathrm{~s}^{-1}$.

14

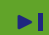

Back

Close

Full Screen / Esc

Printer-friendly Version

Interactive Discussion 


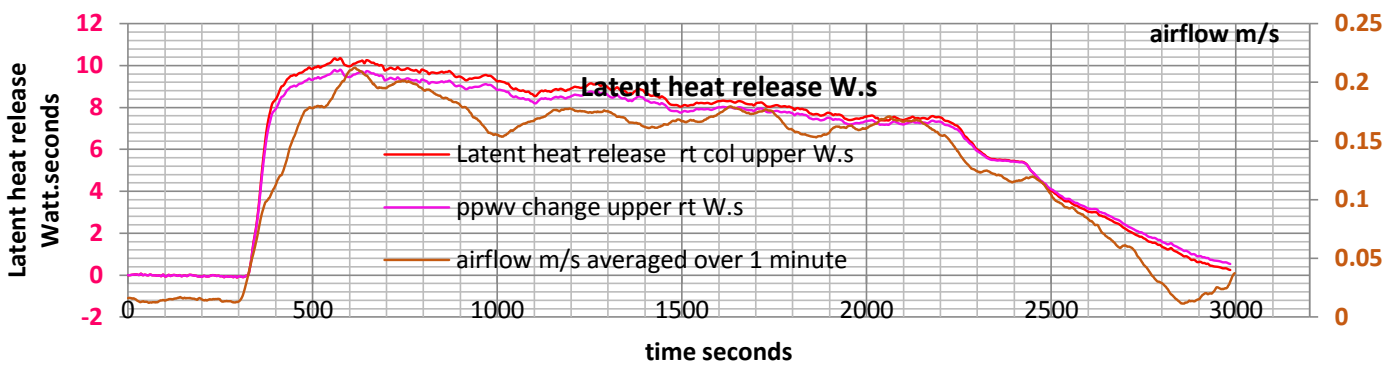

Figure 27. Experiment 27 July 2015. Cumulative Latent heat release Ws from calculated per second quantity of condensate (purple) and of partial pressure change (red). The two curves coincide confirming the two modes of calculation, one from gram quantity of condensate and the other from pressure change. The right axis is airflow (brown).

\section{HESSD}

12, 10921-10974, 2015

\section{Experimental \\ evidence of}

condensation-driven airflow

\section{P. Bunyard et al.}

Title Page

Abstract

Introduction

Conclusions

References

Tables

Figures

14

(nack

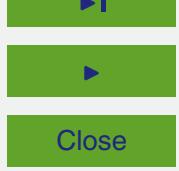

Full Screen / Esc

Printer-friendly Version

Interactive Discussion 


\section{HESSD}

12, 10921-10974, 2015

\section{Experimental \\ evidence of}

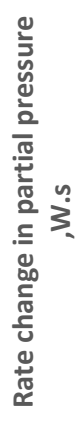

Specific humidity versus pressure change, Watt.seconds and the resulting
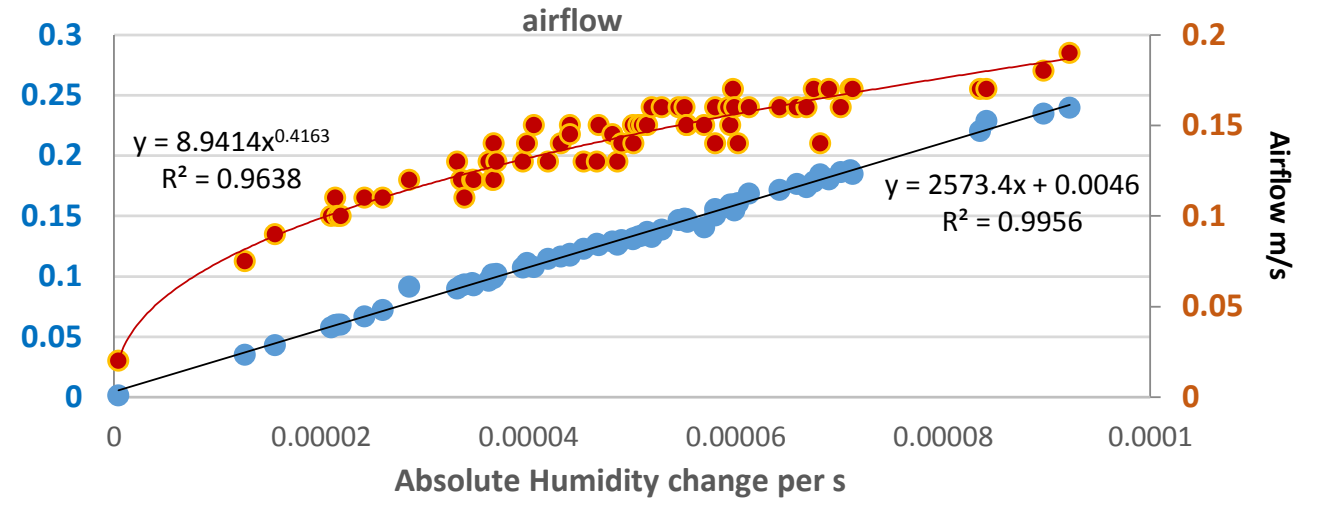

Figure 28. Collected data from 60 experiments with differing initial conditions. The straight-line curve (blue) left $y$ axis, shows the direct relationship between the partial pressure change in Ws and the rate of change in specific humidity, $\mathrm{kg} / \mathrm{second}$. The right-hand $y$ axis shows the measured airflow $\mathrm{m} \mathrm{s}^{-1}$ (brown) with a power law relationship to the rate of change in specific humidity.

\section{airflow}

P. Bunyard et al.

Title Page

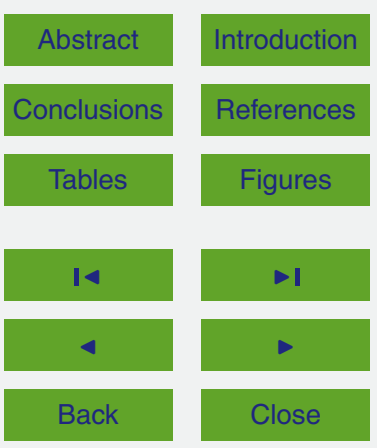

Full Screen / Esc

Printer-friendly Version

Interactive Discussion 
pressure change per second and the resulting airflow $\mathrm{m} / \mathrm{s}$

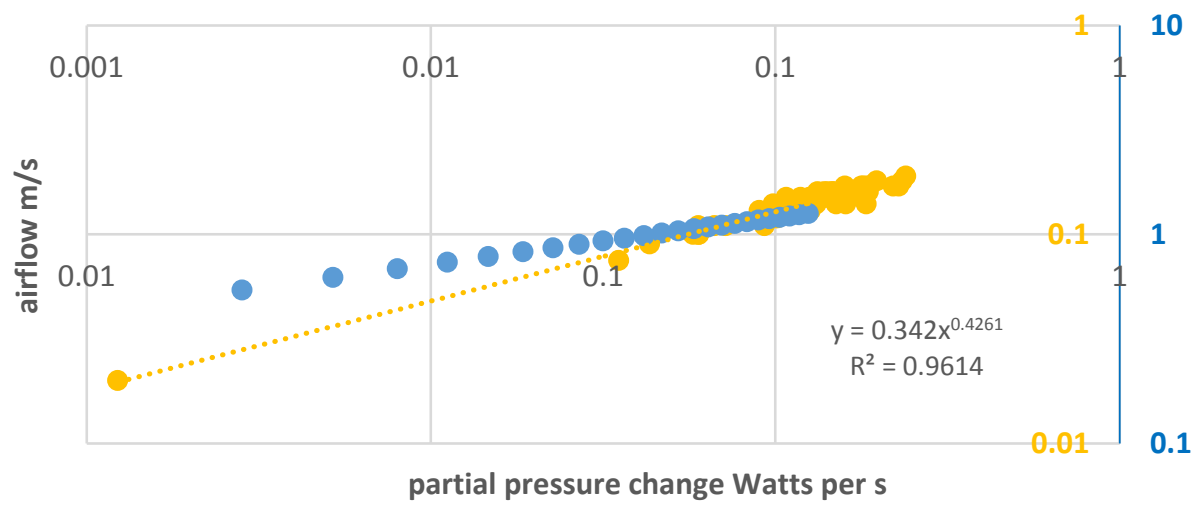

Figure 29. The relationship between airflow and the change in the partial pressure of water fits a power law. The curve of the actual airflow (yellow) corresponds well with the curve of the expected theoretical relationship in relation to the kinetic energy of the partial pressure change in Ws (blue) $R^{2}$. Both axes log to base 10 .

\section{HESSD}

12, 10921-10974, 2015

\section{Experimental}

evidence of

condensation-driven airflow

\section{P. Bunyard et al.}

Title Page

Abstract

Introduction

Conclusions

References

Tables

Figures

14

Back

Close

Full Screen / Esc

Printer-friendly Version

Interactive Discussion 


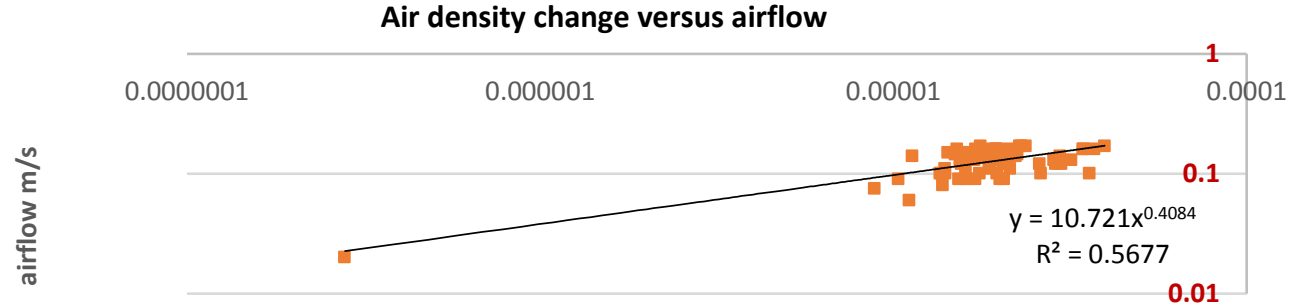

cool air density W.s

Figure 30. The relationship between the changing air density of the cooled parcel of air and airflow. Not only is the kinetic energy of the cooling air (brown) four orders of magnitude less than that of the partial pressure change but it shows a poorer correlation. Both axes logarithmic to base 10 .

\section{HESSD}

12, 10921-10974, 2015

\section{Experimental}

evidence of

condensation-driven airflow

\section{P. Bunyard et al.}

Title Page

Abstract

Introduction

Conclusions

References

Tables

Figures

14

Back

Close

Full Screen / Esc

Printer-friendly Version

Interactive Discussion 


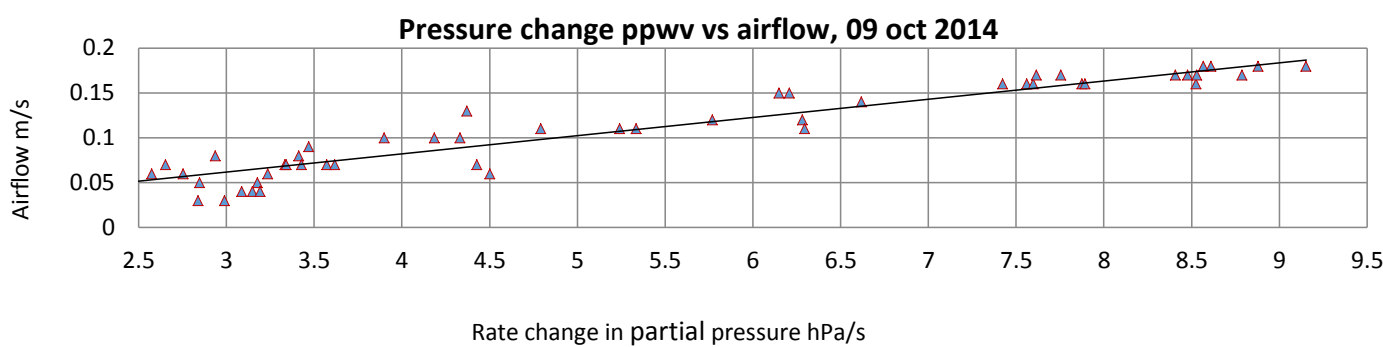

Figure 31. Correlation between partial pressure change $\mathrm{hPa} \mathrm{s} \mathrm{s}^{-1}$, and airflow $\mathrm{m} \mathrm{s}^{-1}$, during experiment 9 October 2014. $X$ axis partial pressure change; $y$ axis airflow. Correlation $R^{2}$, 0.97 .

\section{HESSD}

12, 10921-10974, 2015

\section{Experimental}

evidence of

condensation-driven airflow

\section{P. Bunyard et al.}

Title Page

Abstract

Introduction

Conclusions

References

Tables

Figures

14

Back

Close

Full Screen / Esc

Printer-friendly Version

Interactive Discussion 


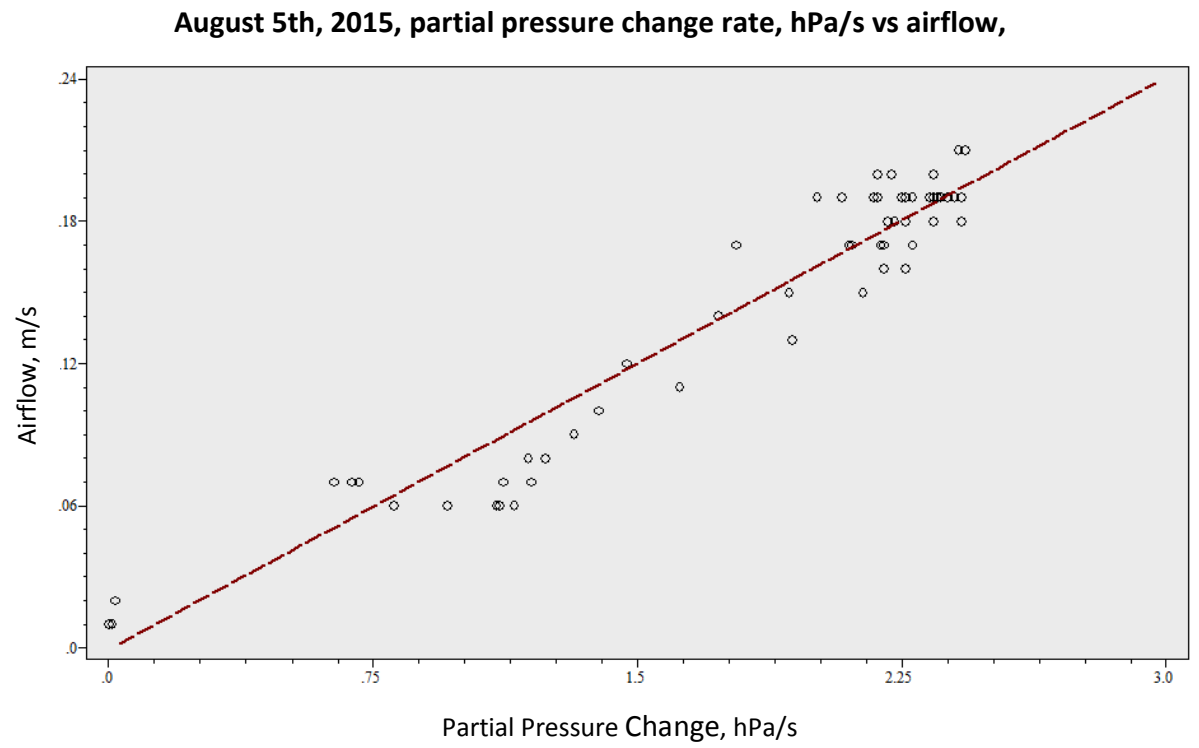

Figure 32. Experiment 5 August 2015, showing significant correlation between partial pressure change and airflow. Correlation coefficient $0.97, R^{2} 0.94$.

\section{HESSD}

12, 10921-10974, 2015

\section{Experimental evidence of}

condensation-driven airflow

\section{P. Bunyard et al.}

Title Page

\section{Full Screen / Esc}

Printer-friendly Version

Interactive Discussion 